\title{
Central Bank Transparency and Independence: Updates and New Measures
}

\author{
N. Nergiz Dincer* \\ Barry Eichengreen**
}

The views expressed herein are those of the author and do not necessarily reflect the official views of The Bank of Korea. When reporting or citing it, the author's name should always be stated explicitly.

\footnotetext{
* T.R. Prime Ministry State Planning Organization, Necatibey cad. No:108, Yucetepe, 06100, Ankara, TURKEY, E-mail: nergiz.dincer@gmail.com.

** University of California, Berkeley, Department of Economics, 530 Evans Hall 3880, Berkeley, CA 94720-3880, E-mail: eichengr@econ.berkeley.edu.
} 


\section{Contents}

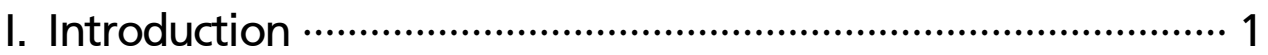

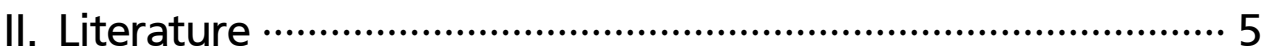

III. Trends and Determinants of Transparency …...................... 8

IV. Measures of Central Bank Independence ….................... 22

V. Trends in Central Bank Independence ……....................... 25

Vl. Conclusion …............................................................................ 36

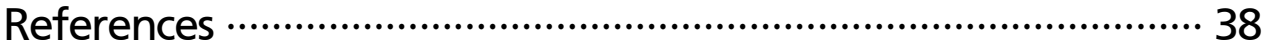

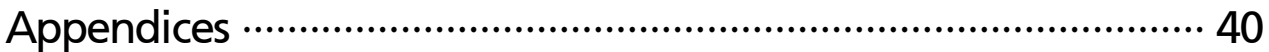




\section{Central Bank Transparency and Independence: Updates and New Measures}

This paper reports updated measures of transparency and independence for more than 100 central banks. The indices show that there has been steady movement in the direction of greater transparency and independence over time. In addition, we show that outcomes such as the variability of inflation are significantly affected by both central bank transparency and independence. Disentangling the impact of the two dimensions of central bank arrangements remains difficult, however.

Keywords: Central Bank, Transparency, Independence

JEL Classification: E0, E4, F0 


\section{Introduction}

In early 2012 the Federal Open Market Committee made known a decision to further increase the transparency of its monetary policy decisions. ${ }^{1)}$ It announced a plan to publish the predictions of members of the Board of Governors and Reserve Bank presidents of the level of short term interest rates as well as having them describe their views of the evolution of the Fed's investment portfolio. The Fed already published their forecasts of inflation, unemployment and growth. In taking this additional step it was following the central banks of New Zealand, Norway and, Sweden, which have been publishing interest rate forecasts for years. More broadly, this decision to release interest rate forecasts and portfolio outlooks was another step in the trend toward greater central bank transparency that has not been limited to this small handful of countries but has been underway globally for some years now.

This trend toward heightened transparency is a departure from long-standing central bank practice which valued confidentiality. Early central banks engaged in commercial banking business; they cloaked their lending decisions in secrecy in order to maintain an advantage over their competitors and out of respect to their clients. As bankers to the government, they sought to avoid releasing embarrassing information about the public finances. As they became lenders of last resort, they sought to avoid undermining confidence in distressed financial institutions by husbanding information about their emergency operations.

The rise of central bank transparency can be understood in a number of related ways. First, it is part of a broader trend, responding to popular pressure, to make government more responsive to the public. In New Zealand, for example, the increase in central bank transparency associated with the Reserve Bank Act of 1989, a parliamentary act that required the rationale for monetary policy decisions to be publicly disclosed, was part of a broader movement associated with the Official Information Act of 1982 and effort of the Labour Government elected in 1984 to enhance the transparency and efficiency of government operations generally.

1) The decision was contained in the minutes of the FOMC for December 2011, released on January 3rd, 2012. 
Second, transparency is seen as a key element of accountability in an era of central bank independence. As central banks have become more independent and freer to choose their tactics, transparency has come to be seen as a mechanism enabling the public to assess whether the actions of central bankers are consistent with their mandate. Central bank independence is widely advocated as a means of insulating monetary from short-term political pressures; it is seen as an efficient means of addressing the time-consistency problems that plague discretionary policy.2) But "with independence, comes ‥ responsibility," as Siklos (2011, p.929) puts it. "Democratic accountability for unelected officials and arm's length institutions necessitates behavior that demonstrates sensitivity for the public's need to understand how policy is made."3) Pressure for transparency is more intense insofar as the mandate of central banks extends beyond the pursuit of easily quantifiable, independently verifiable targets like the rate of inflation to encompass emergency lending, securities market intervention, and related financial operations. In the United States, for example, calls to audit the Fed have intensified as the central bank has come to rely more extensively on unconventional policies and expanded the range of its interventions in securities markets. The FOMC's decision to make more information publicly available can thus be understood as an effort to reconcile the increased complexity of its operations with the desire to maintain and defend its independence.

Third, central bank transparency is seen as way of enabling markets to respond more smoothly to policy decisions. When a central bank is more transparent about its economic outlook and about how that outlook is related to its policy stance, monetary policy decisions are less likely to come as a surprise. Investors are less likely to be caught unawares by policy actions. Policy changes are less likely to cause

2) On these two arguments see Blinder (1998) and Rogoff (1985), respectively. Walsh (2003) emphasizes the importance of distinguishing two aspects of independence: insulation from politics when it comes to defining the objectives of monetary policy; and the independence to freely implement policy once those goals have been defined. Grilli, Masciandaro and Tabellini (1991), in an early, influential article on this subject, called them political and economic independence, respectively. Debelle and Fischer (1994) refer to them as goal and instrument independence.

3) There is also an argument that more independent central banks have greater incentive to clearly communicate their policies (they will want to be more transparent) simply because they have more control over their own policies (Crowe and Meade 2008). 
sharp movements in asset prices that cause financial distress. ${ }^{4)}$

Fourth, transparency is a means of enhancing the credibility of the central bank's commitments. A commitment to ensuring low and stable inflation will be more convincing when the central bank explains in detail how and why its policies are supposed to produce the desired inflation rate. In turn, that more credible commitment gives the central bank more leeway to deviate from typical policy settings when atypical conditions arise, since it will be clear to the public that the deviation is temporary and not inconsistent with the longer run pursuit of the monetary-policy target. Transparency enhances not just policy credibility, in other words, but also policy flexibility.

It follows that transparency about policy is a way to manage expectations, which can matter importantly for the effectiveness of policy, in general but especially under exceptional conditions. While the central bank sets certain short-term interest rates, the long-term rates on which, inter alia, fixed investment decisions depend are a function of not just current short-term rates but also expected future short-term rates. Releasing forecasts of future rates, along with forecasts of future economic conditions to make those future-rate forecasts credible, is a way for the central bank to influence long-term rates and associated private-sector decisions. Announcements that create expectations about future policy can be especially important in periods when current policy is constrained. Thus, the Fed, having cut current short-term interest rates to near zero, must now attempt to affect economic activity by creating expectations of low future short-term rates - by announcing that short-term rates will remain at current near-zero levels for some number of quarters or years thereby influencing the long-term rates on which the costs of borrowing for home purchases and corporate fixed investment depend. Publishing forecasts of future in-

4) There is also the criticism that excessive transparency and information ends up confusing the markets. Clare and Cortenay (2001) argued that minutes recounting contentious discussions among board members can heighten asset-price volatility and end up confusing investors. This is presumably why the Fed trims officials' forecasts before publishing them. It is presumably one reason why the European Central Bank continues to refuse to publish its minutes and the votes and forecasts of board members. Mishkin (2004) similarly warns that a high degree of transparency could disrupt communication with the public, which might not easily understand that forecasts for the policy instrument are conditional and which might misinterpret changes in the forecast (or deviations between forecast and realized rates) as the central bank reneging on its commitments. 
terest rates and, more generally, providing more information about likely future stance- becoming more transparent, in other words - is a means to this end.

Understanding the extent of the trend, its motivations and its implications requires measures of the transparency of central banks. In previous papers (Dincer and Eichengreen, 2008, 2010) we have provided estimates of the extent of transparency for central banks from 1998 through 2006. Here we update those measures through 2010. We use the updated data to ask whether the trend toward greater central bank transparency has continued or instead plateaued, as some have argued.5) This also allows us to ask how the global financial crisis and central bank response affected the trend toward greater central bank transparency. The Fed's response, as discussed above, would suggest that the trend toward greater transparency should have been reinforced insofar as the crisis caused central banks to take unconventional and unprecedented actions. But whether the trend toward greater transparency is in fact general is an empirical question. We attempt to answer it below.

In this paper we also provide new measures of transparency for 20 central banks, mainly those of emerging markets and developed countries that we were not able to consider previously. This speaks further to the question of whether the trend toward increased central bank transparency is general. It helps to address the assertion, sometimes heard, that the trend toward greater transparency is primarily an advanced-country phenomenon that is not equally evident among central banks in developing economies. $\left.{ }^{6}\right)$

We also supplement our data base with new measures of central bank independence, building on the earlier empirical literature on this subject. Transparency and independence are likely to be related attributes of central banks, as explained above. We consider their relationship in the analysis below.

Finally, with these new measures in hand, we reconsider the determinants of central bank transparency and its effects on, inter alia, the dynamics of inflation.

5) See inter alia Siklos (2011).

6) See the Crowe and Meade (2008) paper discussed below. 


\section{Literature}

An early landmark in the literature on central bank transparency is Fry et al. (2000). A strength of the Fry et al. analysis is its wide country coverage, based on a Bank of England-administered survey of 94 central banks. A limitation is its relatively coarse definition of transparency. Fry et al. measured central bank transparency as an equally-weighted average of three sub-indicators: whether the central bank provides prompt public explanations of its policy decisions, the frequency and form of forward-looking analysis provided to the public, and the frequency of bulletins, speeches and research papers. Siklos (2002) then provided similar measures for 20 OECD countries but again for only one point in time, the late 1990s.

Eijffinger and Geraats (2006) distinguish more aspects of transparency and consider more than one point in time. Their indices, on which we build, distinguish political transparency (openness about policy objectives), economic transparency (openness about data, models and forecasts), procedural transparency (openness about the way decisions are taken, achieved mainly through the release of minutes and votes), policy transparency (openness about the policy implications, achieved through prompt announcement and explanation of decisions), and operational transparency (openness about the implementation of those decisions, in other words about control errors and macroeconomic disturbances affecting their magnitude). They distinguish three subcategories within each of these five dimensions. Their overall index sums values across these five dimensions, each of which is in turn an equally weighted average of its sub-dimensions. The strength of this approach is its comprehensive, multidimensional definition of transparency; its limitation is that Eijffinger and Geraats construct it for just nine central banks: the Reserve Bank of Australia, Bank of Canada, ECB, Bank of Japan, Reserve Bank of New Zealand, Swedish Riksbank, Swiss National Bank, Bank of England, and Federal Reserve and five years (19982002).7) Their results point sharp differences between more and less transparent central banks, with the Reserve Bank of New Zealand, the Bank of England and the Swedish Riksbank at the top in terms of transparency, and the Reserve Bank of

7) The index covers the period 1998-2002. 
Australia, Bank of Japan and the Swiss National Bank at the bottom. ${ }^{8)}$

In the paper closest to ours, Crowe and Meade (2008) construct indices of both the transparency and independence of central banks. They report transparency in 1998 and 2006 using criteria similar to ours.9) Their measures of transparency cover 37 central banks. Only among advanced countries do they find that transparency rose significantly. There is no evidence of a systematic change in emerging markets. ${ }^{10)}$

To measure central bank independence, Crowe and Meade apply the criteria developed by Cukierman, Webb and Neyapti (1992). First, a central bank is categorized as more independent if its head (the chief executive) is appointed by the board of the central bank and not by the prime minister or minister of finance, is not subject to dismissal, and has a long term in office. These features of the appointment process are important for insulating the head of the central bank from political pressures. Second, independence is taken as grater when policy decisions are taken without direct government involvement. Third, a central bank is classified as more independent if its charter states that price stability is the sole or primary goal of monetary policy. Finally, independence is greater when there are limits on the ability of the government to borrow from the central bank. The authors combine these four aspects into a single index of independence.

Crowe and Meade use information on central bank laws from a data base held by the IMF to update the Cukierman et al. index. Their measure covering 99 countries in 2003 suggests that independence increased significantly in the 1990s and continued to do so since the turn of the century. For developing and emerging economies, all components of the independence index rise significantly. In the advanced countries, however, this is true only of the components capturing disputes

8) A related study is Bini-Smaghi and Gros (2001), who like Eijffinger-Geraats consider 15 aspects of central bank transparency. They implement their index for four countries: the Fed, the Bank of England, the Bank of Japan, and the ECB. De Haan, Amtembrink and Waller (2004) develop a similar index for six countries. In an unpublished companion paper (De Haan and Amtembrink 2002) two of the authors apply a similar methodology to 15 countries.

9) In some country cases, it would appear, in years slightly earlier than 2006 as a function of data availability.

10) However, their data for the two years may not be directly comparable: while the 1998 data are selfreported - they come from the Bank of England survey reported in Fry et al. (2000) - the 2006 data are constructed on the basis of information gleaned from central bank publications and websites. 
with the executive and lending to the government. ${ }^{11)}$ Their regressions suggest that the change in independence between the two periods is a function of initial independence (with a negative coefficient, indicating that central banks that were already relatively independent had less room for further improvement) and democracy (more checks and balances make society more amenable to delegation within the political system). They find a larger increase in independence in countries with less flexible exchange rate regimes (a pegged exchange rate being an alternative to central bank independence as a way of limiting political interference in the day-today conduct of monetary policy).

Crowe and Meade then regress the level of transparency in 2006 on the level of central bank independence and a vector of controls. They find that independence affects transparency positively, as do the flexibility of the exchange rate regime and measures of institutional quality.12)

In Dincer and Eichengreen $(2008,2010)$ we provide indices of transparency for 100 central banks from 1998 to 2005 and 2006, respectively. Siklos (2011) then updates these same transparency indices through 2009. While finding that the degree of central bank transparency continued to rise outside the advanced countries and in Central and Eastern Europe in particular, we find little sign of further increases in the Group of Seven countries and only a modest increase among developing and Asian countries. Siklos finds no impact of the global financial crisis on trends in transparency in these regions.

11) This may reflect the fact that the other components relating to the appointment of the central bank head and existence of a codified objective for monetary policy were already at high levels, having increased previously.

12) An explanation for the exchange rate result is that flexible exchange rates tend to be associated with more transparent monetary policy strategies like inflation targeting. The positive association of transparency with independence plausibly reflects the role of the former as an accountability mechanism for central banks otherwise insulated from the political system. 


\section{Trends and Determinants of Transparency}

We draw our data from information on central banks' websites and statutes, annual reports, and other published documents. ${ }^{13)}$ We gather this information for as large a number of central banks as possible and for every year from 1998 through 2010. Where there was a change in some aspect of transparency over the course of a calendar year, we take the value that prevailed for the largest portion of the year.

We were able to assemble information on transparency for 120 central banks. Most of the omissions are central banks of micro-states: our sample includes the central banks of all large, systemically significant countries. New central banks considered here, in addition to those covered in our previous study, are those of Angola, Azerbaijan, Bosnia and Herzegovina, Botswana, Cambodia, the Cayman Islands, Curacoa, Iran, Lebanon, Macoa, Macedonia, Mozambique, Samoa, Seychelles, Tanzania, Tonga, Venezuela, Laos, the Maldives and Syria.

Since we have discussed the criteria used in constructing these indices in a series of earlier papers, we do not repeat that discussion here. Readers can find the relevant details in Appendix A.

Table 1: Transparency by Country \& Region (Unweighted), Indices Range from 0 to 15

\begin{tabular}{l|c|c|c|c|c|c|c|c|c|c|c|c|c} 
& 1998 & 1999 & 2000 & 2001 & 2002 & 2003 & 2004 & 2005 & 2006 & 2007 & 2008 & 2009 & 2010 \\
\hline Africa & 2.4 & 2.4 & 2.6 & 2.9 & 3.1 & 3.3 & 3.5 & 3.8 & 3.9 & 4.2 & 4.4 & 4.5 & 4.4 \\
\hline Eastern Africa & 2.1 & 2.1 & 2.3 & 2.6 & 2.9 & 2.9 & 3.1 & 3.3 & 3.5 & 3.7 & 3.8 & 4.0 & 3.8 \\
\hline Ethiopia & 1 & 1 & 1 & 1 & 1 & 1 & 1 & 1 & 1 & 1 & 1 & 2 & 2.5 \\
\hline Kenya & 2.5 & 2.5 & 3 & 4 & 4 & 4 & 4 & 4.5 & 6 & 7 & 7 & 7 & 7 \\
\hline Malawi & 1 & 1 & 1 & 3 & 3 & 3 & 3 & 3 & 3 & 3 & 3 & 3 & 2 \\
\hline Mauritius & 4 & 4 & 4 & 4.5 & 6 & 6 & 6 & 6 & 6 & 6.5 & 6.5 & 6.5 & 6.5 \\
\hline Mozambique & 4 & 4 & 4.5 & 4.5 & 4.5 & 4.5 & 4.5 & 4.5 & 4.5 & 4.5 & 5 & 6 & 5 \\
\hline Rwanda & 1 & 1 & 1 & 1 & 1 & 1 & 1 & 2 & 2 & 2.5 & 3.5 & 3.5 & 3.5 \\
\hline Seychelles & 2 & 2 & 2 & 2 & 2 & 2 & 4 & 4 & 4 & 4 & 3.5 & 3.5 & 3.5 \\
\hline Tanzania & 1.5 & 1.5 & 1.5 & 1.5 & 2.5 & 2.5 & 2.5 & 2.5 & 2.5 & 2.5 & 2.5 & 2.5 & 2.5 \\
\hline Uganda & 2 & 2.5 & 3 & 3 & 3 & 3 & 3 & 3 & 3 & 3 & 3 & 3 & 3 \\
\hline Zambia & 1.5 & 1.5 & 1.5 & 1.5 & 1.5 & 1.5 & 1.5 & 2.5 & 2.5 & 2.5 & 2.5 & 2.5 & 2.5 \\
\hline Northern Africa & 1.5 & 1.5 & 1.8 & 1.8 & 2.1 & 2.3 & 2.4 & 2.8 & 3.3 & 3.6 & 3.6 & 3.6 & 3.6 \\
\hline
\end{tabular}

13) Rather than sending a survey instrument to the central banks themselves and relying on the subjectivity of responding staff. 


\section{$9 \quad$ BOK Working Paper No.2013-21 (2013.09)}

\begin{tabular}{|c|c|c|c|c|c|c|c|c|c|c|c|c|c|}
\hline & 1998 & 1999 & 2000 & 2001 & 2002 & 2003 & 2004 & 2005 & 2006 & 2007 & 2008 & 2009 & 2010 \\
\hline Egypt & 1 & 1 & 1 & 1 & 1 & 1.5 & 2 & 3.5 & 5 & 5 & 5 & 5 & 5 \\
\hline Libyan Arab Jamahiriya & 1 & 1 & 1 & 1 & 1 & 1 & 1 & 1 & 1 & 1 & 1 & 1 & 1 \\
\hline Sudan & 1 & 1 & 2 & 2 & 2 & 2 & 2 & 2 & 2 & 3 & 3 & 3 & 3 \\
\hline Tunisia & 3 & 3 & 3 & 3 & 4.5 & 4.5 & 4.5 & 4.5 & 5 & 5.5 & 5.5 & 5.5 & 5.5 \\
\hline Middle Africa & 1 & 1 & 1 & 1 & 1 & 1 & 1 & 1 & 1 & 1 & 1 & 1 & 1 \\
\hline Angola & 1 & 1 & 1 & 1 & 1 & 1 & 1 & 1 & 1 & 1 & 1 & 1 & 1 \\
\hline Southern Africa & 3.8 & 3.9 & 4.4 & 5.0 & 5.3 & 5.5 & 6.0 & 7.0 & 7.0 & 7.0 & 7.0 & 7.3 & 7.0 \\
\hline Botswana & 5 & 5.5 & 5.5 & 5.5 & 5.5 & 5.5 & 6 & 6 & 6 & 6 & 6 & 6 & 6 \\
\hline Lesotho & 2 & 2 & 2.5 & 2.5 & 2.5 & 3.5 & 3.5 & 6 & 6 & 6 & 6 & 6 & 6 \\
\hline Namibia & 3 & 3 & 3.5 & 3.5 & 4.5 & 4.5 & 6 & 7.5 & 7.5 & 7.5 & 7.5 & 8.5 & 7.5 \\
\hline South Africa & 5 & 5 & 6 & 8.5 & 8.5 & 8.5 & 8.5 & 8.5 & 8.5 & 8.5 & 8.5 & 8.5 & 8.5 \\
\hline Western Africa & 3.7 & 3.7 & 3.7 & 4.0 & 4.3 & 4.8 & 4.8 & 4.8 & 4.8 & 5.5 & 6.7 & 6.7 & 6.7 \\
\hline Ghana & 3 & 3 & 3 & 3 & 4 & 5.5 & 5.5 & 5.5 & 5.5 & 6.5 & 7 & 7 & 7 \\
\hline Nigeria & 4 & 4 & 4 & 4.5 & 4.5 & 4.5 & 4.5 & 4.5 & 4.5 & 5 & 6.5 & 6.5 & 6.5 \\
\hline Sierra Leone & 4 & 4 & 4 & 4.5 & 4.5 & 4.5 & 4.5 & 4.5 & 4.5 & 5 & 6.5 & 6.5 & 6.5 \\
\hline Americas & 3.8 & 4.0 & 4.2 & 4.5 & 4.7 & 4.9 & 5.3 & 5.3 & 5.4 & 5.4 & 5.3 & 5.4 & 5.4 \\
\hline Latin A. \& Carib. & 2.4 & 2.5 & 2.6 & 3.0 & 3.3 & 3.4 & 3.6 & 3.7 & 3.6 & 3.6 & 3.6 & 3.6 & 3.6 \\
\hline East Caribbean & 3 & 3 & 3.5 & 6 & 6 & 6 & 6 & 6 & 6 & 6 & 6 & 6 & 6 \\
\hline Aruba & 0.5 & 0.5 & 0.5 & 0.5 & 0.5 & 0.5 & 0.5 & 0.5 & 0.5 & 0.5 & 0.5 & 1 & 1 \\
\hline Bahamas & 4.5 & 4.5 & 4.5 & 4.5 & 4.5 & 4.5 & 4.5 & 4.5 & 4.5 & 4.5 & 4.5 & 4.5 & 4.5 \\
\hline Barbados & 2.5 & 3 & 3 & 3 & 4 & 4 & 4 & 4 & 4 & 4 & 3.5 & 3.5 & 3.5 \\
\hline Cayman Islands & 0 & 0 & 0 & 0 & 0 & 0 & 0 & 0 & 0 & 0 & 0 & 0 & 0 \\
\hline Cuba & 2.5 & 2.5 & 2.5 & 2.5 & 2.5 & 2.5 & 2.5 & 2.5 & 2.5 & 2.5 & 2.5 & 2.5 & 2.5 \\
\hline Curacao & 3 & 3 & 3 & 3 & 3 & 3.5 & 3.5 & 3.5 & 3.5 & 3.5 & 3.5 & 3.5 & 3.5 \\
\hline Jamaica & 3 & 3 & 3 & 4.5 & 6.5 & 6.5 & 6.5 & 6.5 & 5.5 & 5.5 & 5.5 & 5.5 & 5.5 \\
\hline Trinidad and Tobago & 3 & 3 & 3 & 3 & 3 & 3.5 & 5 & 6 & 6 & 6 & 6 & 6 & 6 \\
\hline Centra America & 2.5 & 2.5 & 2.5 & 3.0 & 3.1 & 3.3 & 4.4 & 4.4 & 4.8 & 4.8 & 4.8 & 4.8 & 4.8 \\
\hline Belize & 2 & 2 & 2 & 3 & 3 & 3 & 3 & 3 & 3 & 3 & 3 & 3 & 3 \\
\hline El Salvador & 2 & 2 & 2 & 3 & 3 & 3 & 3 & 3 & 3 & 3 & 3 & 3 & 3 \\
\hline Guatemala & 1.5 & 1.5 & 1.5 & 1.5 & 2 & 2 & 5.5 & 5.5 & 7 & 7 & 7 & 7 & 7 \\
\hline Mexico & 4.5 & 4.5 & 4.5 & 4.5 & 4.5 & 5 & 6 & 6 & 6 & 6 & 6 & 6 & 6 \\
\hline South America & 3.4 & 3.8 & 4.5 & 4.9 & 5.3 & 5.6 & 5.7 & 5.7 & 5.6 & 5.4 & 5.3 & 5.5 & 5.8 \\
\hline Argentina & 2 & 2 & 2 & 2 & 2 & 4.5 & 5.5 & 5.5 & 5.5 & 5.5 & 5.5 & 5.5 & 5.5 \\
\hline Brazil & 3.5 & 5.5 & 9 & 9 & 9 & 9 & 9 & 9 & 8 & 6.5 & 6 & 6 & 8.5 \\
\hline Chile & 7 & 7 & 7.5 & 7.5 & 7.5 & 7.5 & 7.5 & 7.5 & 7.5 & 7.5 & 7.5 & 8.5 & 8.5 \\
\hline Colombia & 2.5 & 3.5 & 5 & 5 & 5.5 & 5.5 & 5.5 & 5.5 & 5.5 & 8.5 & 8 & 7.5 & 7 \\
\hline Guyana & 1.5 & 1.5 & 1.5 & 1.5 & 1.5 & 1.5 & 1.5 & 1.5 & 1.5 & 2 & 2 & 2 & 2 \\
\hline Peru & 5 & 5 & 5 & 6.5 & 7.5 & 7.5 & 7.5 & 7.5 & 7.5 & 7.5 & 7.5 & 8.5 & 8.5 \\
\hline Uruguay & 5 & 5 & 5 & 5 & 5 & 5 & 5 & 5 & 5 & 2 & 2 & 2 & 2 \\
\hline Venezuela & 1 & 1 & 1 & 2.5 & 4 & 4 & 4 & 4 & 4 & 4 & 4 & 4 & 4 \\
\hline Northern America & 6.7 & 7.2 & 7.2 & 7.2 & 7.2 & 7.2 & 7.3 & 7.3 & 7.7 & 7.7 & 7.7 & 7.7 & 7.7 \\
\hline Bermuda & 1 & 1 & 1 & 1 & 1 & 1 & 1 & 1 & 1 & 1 & 1 & 1 & 1 \\
\hline Canada & 10.5 & 10.5 & 10.5 & 10.5 & 10.5 & 10.5 & 11 & 11 & 11 & 11 & 11 & 11 & 11 \\
\hline United States of America & 8.5 & 10 & 10 & 10 & 10 & 10 & 10 & 10 & 11 & 11 & 11 & 11 & 11 \\
\hline Oceania & 4.0 & 4.4 & 4.4 & 4.7 & 5.1 & 5.2 & 5.3 & 5.3 & 5.4 & 5.5 & 5.8 & 5.8 & 5.8 \\
\hline Australia and New Zealand & 9.3 & 10.5 & 10.5 & 10.8 & 11.5 & 11.5 & 11.5 & 11.5 & 11.5 & 11.5 & 12.5 & 12.5 & 12.5 \\
\hline Australia & 8 & 8 & 8 & 8 & 9 & 9 & 9 & 9 & 9 & 9 & 11 & 11 & 11 \\
\hline New Zealand & 10.5 & 13 & 13 & 13.5 & 14 & 14 & 14 & 14 & 14 & 14 & 14 & 14 & 14 \\
\hline
\end{tabular}




\begin{tabular}{|c|c|c|c|c|c|c|c|c|c|c|c|c|c|}
\hline & 1998 & 1999 & 2000 & 2001 & 2002 & 2003 & 2004 & 2005 & 2006 & 2007 & 2008 & 2009 & 2010 \\
\hline Melanesia & 1.5 & 1.5 & 1.5 & 2.1 & 2.3 & 2.4 & 2.6 & 2.6 & 2.6 & 2.6 & 2.6 & 2.6 & 2.5 \\
\hline Fiji & 1.5 & 1.5 & 1.5 & 1.5 & 1.5 & 2 & 2.5 & 2.5 & 2.5 & 2.5 & 2.5 & 2.5 & 2.5 \\
\hline Papua New Guinea & 1.5 & 1.5 & 1.5 & 3 & 3.5 & 3.5 & 3.5 & 3.5 & 3.5 & 3.5 & 3.5 & 3.5 & 3.5 \\
\hline Solomon Islands & 1.5 & 1.5 & 1.5 & 1.5 & 1.5 & 1.5 & 1.5 & 1.5 & 1.5 & 1.5 & 1.5 & 1.5 & 1.5 \\
\hline Vanuatu & 1.5 & 1.5 & 1.5 & 2.5 & 2.5 & 2.5 & 3 & 3 & 3 & 3 & 3 & 3 & 2.5 \\
\hline Polynesia & 1.3 & 1.3 & 1.3 & 1.3 & 1.5 & 1.8 & 1.8 & 1.8 & 2.0 & 2.3 & 2.3 & 2.3 & 2.3 \\
\hline Samoa & 2 & 2 & 2 & 2 & 2.5 & 3 & 3 & 3 & 3.5 & 3.5 & 3.5 & 3.5 & 3.5 \\
\hline Tonga & 0.5 & 0.5 & 0.5 & 0.5 & 0.5 & 0.5 & 0.5 & 0.5 & 0.5 & 1 & 1 & 1 & 1 \\
\hline Asia & 2.8 & 3.0 & 3.3 & 3.5 & 3.9 & 4.2 & 4.4 & 4.7 & 4.9 & 5.0 & 5.1 & 5.0 & 5.1 \\
\hline Central Asia & 2.7 & 2.7 & 2.7 & 3.0 & 3.0 & 2.7 & 3.3 & 4.5 & 4.5 & 4.7 & 4.7 & 4.7 & 4.7 \\
\hline Kazakhstan & 3.5 & 3.5 & 3.5 & 3.5 & 3.5 & 3.5 & 3.5 & 6 & 6 & 6 & 6 & 6 & 6 \\
\hline Kyrgyzstan & 3 & 3 & 3 & 4 & 4 & 3 & 5 & 5 & 5 & 5.5 & 5.5 & 5.5 & 5.5 \\
\hline Tajikistan & 1.5 & 1.5 & 1.5 & 1.5 & 1.5 & 1.5 & 1.5 & 2.5 & 2.5 & 2.5 & 2.5 & 2.5 & 2.5 \\
\hline Eastern Asia & 4.3 & 4.4 & 4.8 & 4.9 & 5.3 & 6.1 & 6.3 & 6.3 & 6.3 & 6.3 & 6.7 & 6.7 & 6.7 \\
\hline China & 1 & 1 & 1 & 1 & 1.5 & 4.5 & 4.5 & 4.5 & 4.5 & 4 & 4 & 4 & 4 \\
\hline Hong Kong & 5 & 6 & 6 & 6 & 7 & 7 & 7 & 7 & 7.5 & 7.5 & 7.5 & 7.5 & 7.5 \\
\hline Korea & 6.5 & 6.5 & 8 & 8.5 & 8.5 & 8.5 & 8.5 & 8.5 & 8.5 & 8.5 & 8.5 & 8.5 & 8.5 \\
\hline Japan & 8 & 8 & 8.5 & 8 & 8 & 8 & 9.5 & 9.5 & 9 & 9 & 10.5 & 10.5 & 10.5 \\
\hline Macao & 3 & 3 & 3 & 3 & 3 & 4.5 & 4.5 & 4.5 & 4.5 & 4.5 & 4.5 & 4.5 & 4.5 \\
\hline Mongolia & 2 & 2 & 2 & 3 & 4 & 4 & 4 & 4 & 4 & 4 & 5 & 5 & 5 \\
\hline Southern Asia & 2.3 & 2.3 & 2.3 & 2.5 & 2.9 & 3.3 & 3.4 & 3.4 & 3.9 & 3.9 & 3.9 & 3.6 & 3.9 \\
\hline Bangladesh & 0 & 0 & 0 & 0.5 & 0.5 & 3 & 3.5 & 3.5 & 4 & 4 & 4 & 4 & 4 \\
\hline Bhutan & 1.5 & 1.5 & 1.5 & 1.5 & 3 & 3 & 3 & 3 & 3 & 3 & 3 & 3 & 4.5 \\
\hline India & 2 & 2 & 2 & 2 & 2 & 2 & 2 & 2 & 3 & 3 & 3 & 3 & 3 \\
\hline Iran & 3 & 3 & 3 & 3 & 3 & 3 & 3 & 3 & 3 & 3 & 3 & 3 & 3 \\
\hline Maldives & 2.5 & 2.5 & 2.5 & 3.5 & 3.5 & 3.5 & 3.5 & 3.5 & 4 & 4 & 4 & 4 & 4 \\
\hline Pakistan & 2 & 2 & 2 & 2 & 2 & 2 & 2 & 2 & 3 & 3 & 3 & 3 & 3 \\
\hline Sri Lanka & 5 & 5 & 5 & 5 & 6.5 & 6.5 & 7 & 7 & 7 & 7 & 7 & 5.5 & 5.5 \\
\hline South-Eastern Asia & 2.5 & 3.1 & 4.1 & 4.3 & 5.0 & 5.6 & 5.8 & 5.9 & 6.0 & 5.9 & 5.9 & 6.0 & 6.2 \\
\hline Cambodia & 2 & 2 & 2 & 2 & 2 & 2 & 2.5 & 2.5 & 2.5 & 2.5 & 2.5 & 2.5 & 2.5 \\
\hline Indonesia & 3 & 4.5 & 4.5 & 4.5 & 4.5 & 7 & 8 & 8 & 8.5 & 8.5 & 8.5 & 8.5 & 9 \\
\hline Lao People's democratic & 0 & 0 & 1.5 & 1 & 1.5 & 1.5 & 1.5 & 1.5 & 1.5 & 1.5 & 1.5 & 1.5 & 1.5 \\
\hline Malaysia & 4.5 & 4.5 & 6 & 6 & 6 & 6 & 6 & 6 & 6 & 6 & 6 & 6 & 6 \\
\hline Philippines & 3.5 & 5 & 5 & 6 & 10 & 10 & 10 & 10 & 10 & 9 & 9 & 9 & 10 \\
\hline Singapore & 2.5 & 4 & 4 & 4 & 3 & 4.5 & 4.5 & 5.5 & 5.5 & 5.5 & 5.5 & 5.5 & 5.5 \\
\hline Thailand & 2 & 2 & 6 & 6.5 & 8 & 8 & 8 & 8 & 8 & 8 & 8.5 & 9 & 9 \\
\hline Western Asia & 2.2 & 2.3 & 2.5 & 2.9 & 3.2 & 3.3 & 3.4 & 3.5 & 3.9 & 4.1 & 4.2 & 4.2 & 4.3 \\
\hline Armenia & 4 & 4 & 4 & 4 & 4 & 4 & 4 & 4 & 7.5 & 7.5 & 7.5 & 7.5 & 8.5 \\
\hline Azarbaijan & 1 & 1 & 1 & 3 & 3 & 3 & 3 & 3.5 & 3.5 & 3.5 & 3.5 & 3.5 & 3.5 \\
\hline Bahrain & 3 & 3 & 3 & 3 & 3 & 3 & 3 & 3.5 & 3.5 & 4 & 4 & 4 & 4 \\
\hline Cyprus & 2.5 & 3.5 & 3.5 & 4.5 & 7 & 7 & 7.5 & 7.5 & 7.5 & 7.5 & & & \\
\hline Georgia & 3 & 3 & 3 & 3 & 3 & 4 & 4 & 4 & 4.5 & 5.5 & 6.5 & 7.5 & 7.5 \\
\hline Iraq & 2 & 2 & 2 & 2 & 2 & 2 & 2.5 & 2.5 & 2.5 & 2.5 & 2.5 & 2.5 & 2.5 \\
\hline Israel & 5.5 & 7 & 7.5 & 8.5 & 8.5 & 8.5 & 8.5 & 8.5 & 10 & 10 & 11 & 11 & 11.5 \\
\hline Jordan & 1 & 1 & 1 & 1 & 1 & 1 & 1.5 & 2 & 2 & 2.5 & 2.5 & 2.5 & 1.5 \\
\hline Kuwait & 2 & 2 & 2 & 2 & 2 & 2 & 2 & 3.5 & 3.5 & 3.5 & 3.5 & 3.5 & 3.5 \\
\hline Lebanon & 1.5 & 1.5 & 1.5 & 1.5 & 1.5 & 1.5 & 1.5 & 1.5 & 1.5 & 1.5 & 1.5 & 1.5 & 1.5 \\
\hline Oman & 1.5 & 1.5 & 2 & 2 & 2.5 & 2.5 & 2.5 & 2.5 & 2.5 & 2.5 & 3 & 3 & 3 \\
\hline
\end{tabular}




\begin{tabular}{|c|c|c|c|c|c|c|c|c|c|c|c|c|c|}
\hline & 1998 & 1999 & 2000 & 2001 & 2002 & 2003 & 2004 & 2005 & 2006 & 2007 & 2008 & 2009 & 2010 \\
\hline Qatar & 3 & 3 & 3 & 3 & 3 & 3 & 3 & 3 & 3 & 3.5 & 3.5 & 3.5 & 3.5 \\
\hline Saudi Arabia & 1 & 1 & 1 & 1 & 1 & 1 & 1 & 1 & 1 & 1 & 2 & 2 & 2 \\
\hline Syria & 0.5 & 0.5 & 0.5 & 0.5 & 0.5 & 0.5 & 0.5 & 0.5 & 0.5 & 0.5 & 0.5 & 0.5 & 0.5 \\
\hline Turkey & 3 & 2 & 4 & 5.5 & 8.5 & 8.5 & 8.5 & 8.5 & 10 & 10 & 10 & 10 & 10 \\
\hline United Arab Emirates & 2 & 2 & 2 & 2 & 2 & 2 & 2 & 2 & 2 & 3 & 3 & 3 & 3 \\
\hline Yemen & 1 & 1 & 2 & 2 & 2 & 2 & 2 & 2 & 2 & 2 & 2 & 2 & 2 \\
\hline Europe & 5.3 & 5.6 & 6.0 & 6.4 & 7.0 & 7.4 & 7.7 & 7.8 & 8.0 & 8.1 & 8.1 & 8.3 & 8.4 \\
\hline Eastern Europe & 3.5 & 4.0 & 4.4 & 4.7 & 5.6 & 5.7 & 6.3 & 6.6 & 7.1 & 7.2 & 7.3 & 7.3 & 7.6 \\
\hline Belarus & 1.5 & 3.5 & 5 & 5 & 5 & 5 & 5 & 5 & 5 & 5 & 5 & 5 & 5 \\
\hline Bulgaria & 4.5 & 4.5 & 4.5 & 4.5 & 4.5 & 4.5 & 5 & 5.5 & 5.5 & 5.5 & 5.5 & 5.5 & 5.5 \\
\hline Czech Republic & 8.5 & 9.5 & 9.5 & 9.5 & 10 & 11 & 11.5 & 11.5 & 11.5 & 11.5 & 12 & 12 & 12 \\
\hline Hungary & 3.5 & 3.5 & 5.5 & 6.5 & 9 & 9 & 9 & 10.5 & 11 & 12 & 13.5 & 13.5 & 13.5 \\
\hline Poland & 3 & 5 & 5 & 6.5 & 6.5 & 6.5 & 7 & 8 & 9 & 10 & 9 & 9 & 9 \\
\hline Republic of Moldova & 5 & 5 & 5 & 6 & 6.5 & 6.5 & 6.5 & 6.5 & 6.5 & 6.5 & 7 & 7 & 8 \\
\hline Romania & 1.5 & 1.5 & 1.5 & 1.5 & 4.5 & 4.5 & 7 & 7 & 7.5 & 7.5 & 7.5 & 7.5 & 7.5 \\
\hline Russian Federation & 1.5 & 1.5 & 1.5 & 1.5 & 1.5 & 1.5 & 3 & 3 & 3 & 3 & 3 & 3 & 3 \\
\hline Slovakia & 4 & 4 & 4.5 & 3.5 & 5.5 & 5.5 & 5.5 & 6 & 8 & & & & \\
\hline Ukraine & 2 & 2 & 2 & 2 & 3 & 3 & 3 & 3 & 3.5 & 3.5 & 3.5 & 3.5 & 5 \\
\hline Northern Europe & 6.6 & 6.8 & 7.4 & 7.7 & 8.1 & 8.3 & 8.3 & 8.4 & 8.9 & 9.1 & 9.3 & 9.4 & 9.6 \\
\hline Denmark & 5.5 & 5.5 & 5.5 & 5.5 & 5.5 & 6.5 & 6.5 & 6.5 & 6.5 & 7.5 & 8 & 8 & 8 \\
\hline Estonia & 5 & 5 & 5.5 & 5.5 & 5.5 & 5.5 & 5 & 5.5 & 6.5 & 6.5 & 6.5 & 6.5 & 6.5 \\
\hline Iceland & 5.5 & 5.5 & 7 & 7 & 7.5 & 7.5 & 7.5 & 7.5 & 8 & 8 & 8 & 10.5 & 10.5 \\
\hline Latvia & 7 & 7 & 7 & 7 & 7 & 7.5 & 7.5 & 7.5 & 8.5 & 8.5 & 8.5 & 8 & 9 \\
\hline Lithuania & 4 & 4 & 4.5 & 5 & 5 & 5 & 5 & 5 & 5.5 & 5.5 & 6 & 6 & 6 \\
\hline Norway & 6 & 6 & 6 & 7.5 & 7.5 & 7.5 & 8 & 8 & 9 & 10 & 10 & 10 & 10 \\
\hline Sweden & 9 & 9.5 & 11.5 & 11.5 & 14.5 & 14.5 & 14.5 & 14.5 & 14.5 & 14.5 & 14.5 & 14.5 & 14.5 \\
\hline United Kingdom & 11 & 12 & 12.5 & 12.5 & 12.5 & 12.5 & 12.5 & 12.5 & 12.5 & 12.5 & 12.5 & 12 & 12 \\
\hline Southern Europe & 3.7 & 3.7 & 4.0 & 4.3 & 5.0 & 5.9 & 6.0 & 6.0 & 6.0 & 5.8 & 5.8 & 5.8 & 5.8 \\
\hline Albania & 4.5 & 4.5 & 4.5 & 4.5 & 4.5 & 6 & 6.5 & 6.5 & 6.5 & 8 & 8 & 8 & 8 \\
\hline Bosnia and Herzegovina & 3 & 3 & 3 & 3 & 3.5 & 5.5 & 5.5 & 5.5 & 5.5 & 5.5 & 5.5 & 5.5 & 5.5 \\
\hline Croatia & 1.5 & 1.5 & 1.5 & 2.5 & 2.5 & 2.5 & 2.5 & 2.5 & 2.5 & 2.5 & 2.5 & 2.5 & 2.5 \\
\hline Macedonia & 3 & 3 & 4.5 & 5 & 6.5 & 7 & 7 & 7 & 7 & 7 & 7 & 7 & 7 \\
\hline Malta & 5 & 5 & 5.5 & 5.5 & 5.5 & 7 & 7 & 7 & 7 & & & & \\
\hline Slovenia & 5 & 5 & 5 & 5 & 7.5 & 7.5 & 7.5 & 7.5 & 7.5 & & & & \\
\hline Western Europe & 7.3 & 7.8 & 8.0 & 9.0 & 9.3 & 9.8 & 10.3 & 10.3 & 10.3 & 10.3 & 10.3 & 10.8 & 10.8 \\
\hline Switzerland & 6 & 7 & 7.5 & 8 & 8 & 9 & 9.5 & 9.5 & 9.5 & 9.5 & 9.5 & 10.5 & 10.5 \\
\hline Euro Area & 8.5 & 8.5 & 8.5 & 10 & 10.5 & 10.5 & 11 & 11 & 11 & 11 & 11 & 11 & 11 \\
\hline
\end{tabular}

Table 1 shows the indices by country and region.14) The most transparent central banks in 2010 are the Swedish Riksbank, the Reserve Bank of New Zealand, the Central Bank of Hungary, the Czech National Bank, the Bank of England and the Bank of Israel. We see here a number of central banks that received high marks 
for transparency in past studies (those of Sweden, New Zealand, the UK, Canada) but also others that did not make the top-ten list previously. This is a reminder of the advantages of broad country coverage and of the fact that a number of countries have been moving in the direction of greater transparency.

Table 2: Components of Transparency Index for 20 countries with extreme values (15 subcomponents and total), 2010

\begin{tabular}{l|c|c|c|c|c|c|c|c|c|c|c|c|c|c|c|c} 
& $\mathrm{T}$ & $1 \mathrm{a}$ & $1 \mathrm{~b}$ & $1 \mathrm{c}$ & $2 \mathrm{a}$ & $2 \mathrm{~b}$ & $2 \mathrm{c}$ & $3 \mathrm{a}$ & $3 \mathrm{~b}$ & $3 \mathrm{c}$ & $4 \mathrm{a}$ & $4 \mathrm{~b}$ & $4 \mathrm{c}$ & $5 \mathrm{a}$ & $5 \mathrm{~b}$ & $5 \mathrm{c}$ \\
\hline Sweden & 14.5 & 0.5 & 1 & 1 & 1 & 1 & 1 & 1 & 1 & 1 & 1 & 1 & 1 & 1 & 1 & 1 \\
\hline New Zealand & 14 & 1 & 1 & 1 & 1 & 1 & 1 & 1 & 1 & 1 & 1 & 1 & 1 & 1 & 0.5 & 0.5 \\
\hline Hungary & 13.5 & 1 & 1 & 1 & 1 & 1 & 1 & 1 & 1 & 1 & 1 & 1 & 1 & 0.5 & 0.5 & 0.5 \\
\hline Czech & 12 & 1 & 1 & 1 & 0.5 & 1 & 1 & 1 & 1 & 1 & 1 & 0.5 & 0 & 0 & 1 & 1 \\
\hline United Kingdom & 12 & 0.5 & 1 & 1 & 0.5 & 1 & 1 & 1 & 1 & 1 & 1 & 0.5 & 0 & 1 & 1 & 0.5 \\
\hline Israel & 11.5 & 1 & 1 & 1 & 1 & 1 & 1 & 1 & 1 & 0.5 & 1 & 0.5 & 0 & 0.5 & 0.5 & 0.5 \\
\hline Australia & 8 & 8 & 8 & 8 & 9 & 9 & 9 & 9 & 9 & 9 & 11 & 11 & 11 & 0 & 0 & 0 \\
\hline Canada & 11 & 1 & 1 & 1 & 1 & 1 & 1 & 1 & 0 & 0 & 1 & 1 & 0 & 1 & 0.5 & 0.5 \\
\hline Euro Area & 11 & 1 & 1 & 1 & 1 & 1 & 1 & 1 & 0 & 0 & 1 & 1 & 0 & 1 & 0.5 & 0.5 \\
\hline United States & 11 & 0.5 & 0 & 0.5 & 1 & 1 & 0.5 & 1 & 1 & 1 & 1 & 1 & 1 & 1 & 0 & 0.5 \\
\hline Lao Peoples Republic & 1.5 & 0 & 0 & 0 & 0 & 0 & 0.5 & 1 & 0 & 0 & 0 & 0 & 0 & 0 & 0 & 0 \\
\hline Lebanon & 1.5 & 0.5 & 0 & 1 & 0 & 0 & 0 & 0 & 0 & 0 & 0 & 0 & 0 & 0 & 0 & 0 \\
\hline Solomon Islands & 1.5 & 0.5 & 0 & 0.5 & 0 & 0 & 0.5 & 0 & 0 & 0 & 0 & 0 & 0 & 0 & 0 & 0 \\
\hline Angola & 1 & 1 & 0 & 0 & 0 & 0 & 0 & 0 & 0 & 0 & 0 & 0 & 0 & 0 & 0 & 0 \\
\hline Aruba & 1 & 0 & 0 & 0.5 & 0 & 0 & 0.5 & 0 & 0 & 0 & 0 & 0 & 0 & 0 & 0 & 0 \\
\hline Bermuda & 1 & 0.5 & 0 & 0.5 & 0 & 0 & 0 & 0 & 0 & 0 & 0 & 0 & 0 & 0 & 0 & 0 \\
\hline Libya & 1 & 0.5 & 0 & 0.5 & 0 & 0 & 0 & 0 & 0 & 0 & 0 & 0 & 0 & 0 & 0 & 0 \\
\hline Tonga & 1 & 0.5 & 0 & 0.5 & 0 & 0 & 0 & 0 & 0 & 0 & 0 & 0 & 0 & 0 & 0 & 0 \\
\hline Syria & 0.5 & 0.5 & 0 & 0 & 0 & 0 & 0 & 0 & 0 & 0 & 0 & 0 & 0 & 0 & 0 & 0 \\
\hline Cayman Islands & 0 & 0 & 0 & 0 & 0 & 0 & 0 & 0 & 0 & 0 & 0 & 0 & 0 & 0 & 0 & 0 \\
\hline
\end{tabular}

The six least transparent central banks in 2010 were those of Angola, Aruba, Bermuda, the Cayman Islands, Libya, Syria and Tonga. In 2006, by comparison, they had been those of Aruba, Bermuda, Ethiopia, Libya, Saudi Arabia and Yemen. While some of the names have changed, the categories remain the same; that is to say, many of the least transparent central banks remain those of offshore financial centers and autocratic regimes in North Africa and the Middle East (see Table 2). ${ }^{15}$ )

15) It will be interesting to see what impact recent efforts to combat money laundering and, in addition, the advent of the Arab Spring have on these patterns. 
Figure 1: Comparison of Transparency Index in 1998 and 2010

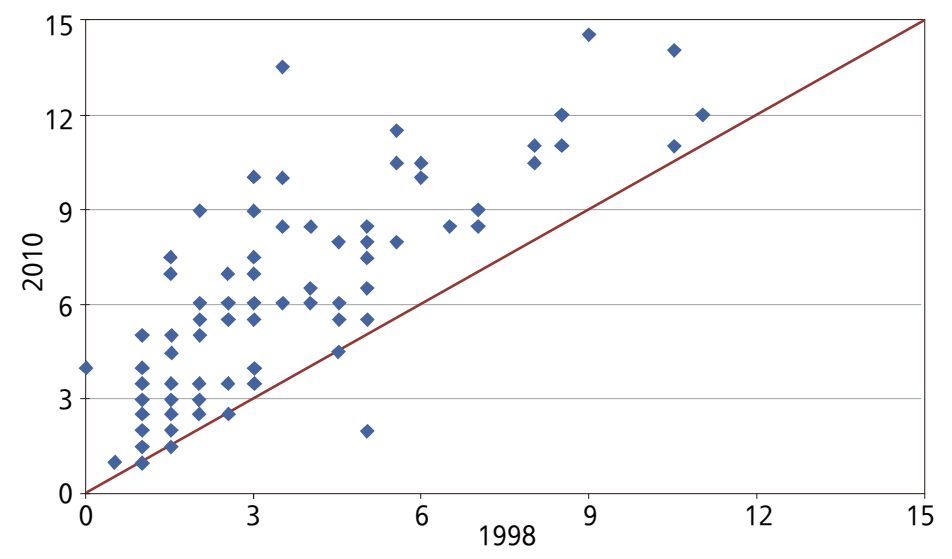

Figure 1 compares our measure of transparency in 1998 and 2010.16) There are only 10 countries (Angola, Bahamas, Bermuda, Cayman Islands, Cuba, Iran, Lebanon, Libya, Solomon Islands and Syria) on the diagonal, indicating no change in transparency, while the remaining 110 cases are all above and to its left, indicating an increase, with one exception. The one exception is Uruguay, which stopped publishing reports in English after 2006 (it has indicated the intention of reversing this change and again publishing reports in English in coming years). The central banks for which the index rose by the most were those of Hungary, Thailand, Turkey and Philippines. ${ }^{17)}$ The average transparency score in the sample rose from 3.2 in 1998 to 5.5 in 2010.18 )

16) With 2010 on the vertical axis.

17) Over the 1998-2010 period, economic and policy transparency increased more than the other components.

18) Unweighted averages. 
Table 3: Regional Transparency Index (Weighted by current US dollar GDP)

\begin{tabular}{|c|c|c|c|c|c|c|c|c|c|c|c|c|c|}
\hline & 1998 & 1999 & 2000 & 2001 & 2002 & 2003 & 2004 & 2005 & 2006 & 2007 & 2008 & 2009 & 2010 \\
\hline Africa & 3.05 & 3.03 & 3.39 & 4.18 & 4.32 & 4.92 & 5.23 & 5.40 & 5.48 & 5.60 & 5.65 & 5.69 & 5.80 \\
\hline Eastern Africa & 2.03 & 2.09 & 2.28 & 2.57 & 2.99 & 3.01 & 3.01 & 3.18 & 3.48 & 3.75 & 3.69 & 3.81 & 3.82 \\
\hline Northern Africa & 1.37 & 1.37 & 1.41 & 1.43 & 1.76 & 2.21 & 2.59 & 3.44 & 4.39 & 4.66 & 4.65 & 4.70 & 4.69 \\
\hline Middle Africa & 1.00 & 1.00 & 1.00 & 1.00 & 1.00 & 1.00 & 1.00 & 1.00 & 1.00 & 1.00 & 1.00 & 1.00 & 1.00 \\
\hline Southern Africa & 4.94 & 4.96 & 5.89 & 8.19 & 8.31 & 8.23 & 8.30 & 8.36 & 8.36 & 8.36 & 8.34 & 8.39 & 8.36 \\
\hline Western Africa & 3.81 & 3.82 & 3.90 & 4.35 & 4.45 & 4.60 & 4.59 & 4.59 & 4.62 & 5.19 & 6.56 & 6.57 & 6.57 \\
\hline Americas & 7.73 & 9.16 & 9.33 & 9.35 & 9.48 & 9.53 & 9.60 & 9.56 & 10.23 & 10.07 & 9.91 & 9.95 & 10.05 \\
\hline Latin A. \& Carib. & 3.27 & 3.33 & 3.33 & 3.85 & 4.67 & 4.71 & 5.29 & 5.72 & 5.44 & 5.47 & 5.48 & 5.40 & 5.38 \\
\hline Central America & 4.30 & 4.33 & 4.35 & 4.38 & 4.39 & 4.87 & 5.92 & 5.92 & 5.97 & 5.97 & 5.97 & 5.97 & 5.98 \\
\hline South America & 3.25 & 4.22 & 6.11 & 6.14 & 7.11 & 7.42 & 7.52 & 7.57 & 7.02 & 6.39 & 6.01 & 6.05 & 7.49 \\
\hline Northern America & 8.63 & 10.03 & 10.03 & 10.03 & 10.03 & 10.04 & 10.08 & 10.08 & 11.00 & 11.00 & 11.00 & 11.00 & 11.00 \\
\hline Oceania & 8.20 & 8.54 & 8.46 & 8.59 & 9.62 & 9.69 & 9.64 & 9.62 & 9.56 & 9.60 & 11.23 & 11.23 & 11.23 \\
\hline Australia and New Zealand & 8.30 & 8.64 & 8.55 & 8.67 & 9.71 & 9.78 & 9.72 & 9.70 & 9.64 & 9.68 & 11.33 & 11.34 & 11.33 \\
\hline Melanesia & 1.50 & 1.50 & 1.50 & 2.40 & 2.65 & 2.81 & 3.01 & 3.04 & 3.06 & 3.06 & 3.10 & 3.13 & 3.13 \\
\hline Polynesia & 1.34 & 1.31 & 1.35 & 1.39 & 1.67 & 1.98 & 2.03 & 2.03 & 2.32 & 2.59 & 2.55 & 2.57 & 2.56 \\
\hline Asia & 5.54 & 5.70 & 6.19 & 5.80 & 5.92 & 6.52 & 7.15 & 6.98 & 6.79 & 6.47 & 6.87 & 6.80 & 6.73 \\
\hline Central Asia & 3.36 & 3.35 & 3.38 & 3.44 & 3.44 & 3.38 & 3.48 & 5.83 & 5.85 & 5.87 & 5.86 & 5.84 & 5.86 \\
\hline Eastern Asia & 6.48 & 6.58 & 7.02 & 6.46 & 6.47 & 7.16 & 8.04 & 7.89 & 7.42 & 6.99 & 7.47 & 7.35 & 7.23 \\
\hline Southern Asia & 1.92 & 1.92 & 1.92 & 1.96 & 2.01 & 2.18 & 2.21 & 2.21 & 3.15 & 3.13 & 3.16 & 3.12 & 3.11 \\
\hline South-Eastern Asia & 2.95 & 3.87 & 5.04 & 5.28 & 5.98 & 7.02 & 7.34 & 7.48 & 7.70 & 7.58 & 7.70 & 7.82 & 8.19 \\
\hline Western Asia & 2.71 & 2.54 & 3.29 & 3.86 & 4.82 & 5.05 & 5.09 & 4.93 & 5.55 & 5.85 & 6.01 & 6.08 & 6.18 \\
\hline Europe & 8.34 & 8.59 & 8.69 & 9.80 & 10.25 & 10.28 & 10.69 & 10.62 & 10.58 & 10.57 & 10.45 & 10.50 & 10.43 \\
\hline Eastern Europe & 2.78 & 3.71 & 3.63 & 4.04 & 4.53 & 4.55 & 5.38 & 5.54 & 5.61 & 5.76 & 5.62 & 5.83 & 5.67 \\
\hline Northern Europe & 9.84 & 10.61 & 11.21 & 11.32 & 11.65 & 11.72 & 11.76 & 11.70 & 11.80 & 11.96 & 11.92 & 11.58 & 11.62 \\
\hline Southern Europe & 2.34 & 2.44 & 2.70 & 3.28 & 3.45 & 4.03 & 4.08 & 4.07 & 3.53 & 3.71 & 3.75 & 3.76 & 3.77 \\
\hline Western Europe & 8.43 & 8.46 & 8.47 & 9.94 & 10.43 & 10.46 & 10.96 & 10.96 & 10.96 & 10.96 & 10.96 & 10.99 & 10.98 \\
\hline
\end{tabular}

GDP weighted averages in Table 3 suggest that Northern Europe, Australia-New Zealand, North America and Western Europe are the most transparent regions. ${ }^{19)}$ Middle Africa (effectively Angola), Polynesia, Melanesia, Southern Asia, Southern Europe and East Africa are the regions with the lowest levels of transparency in 2010. Middle Africa, Polynesia, Melanesia, and Latin America-Caribbean are the least transparent regions when averages are unweighted. In 2006, in contrast, the most transparent region was Australia-New Zealand, followed by Western Europe, Northern Europe, South East Asia, Southern Africa, and North America. ${ }^{20)}$

19) Taking unweighted averages of the countries making up a region suggests that Australia-New Zealand, Western Europe, Northern Europe, North America and Eastern Europe receive the highest transparency scores in descending order.

20) When we take GDP-weighted averages, as in Table 3, the most transparent regions as of 2010, in descending order, are Oceania, North America and Europe (led by Northern Europe); lower weights 
Figure 2: Comparison of Transparency Index in 2008 and 2010

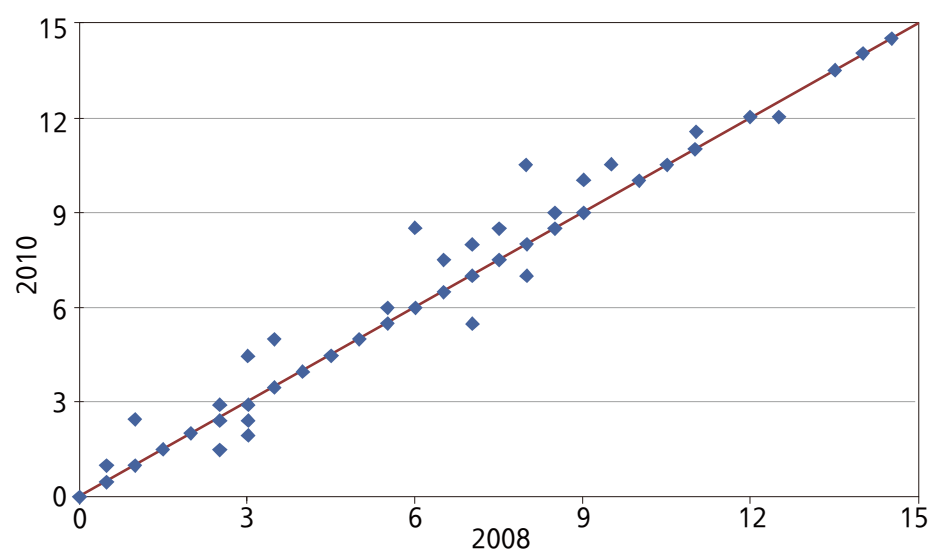

Figure 2 compares 2008 and 2010 as a way of investigating the impact of the global financial crisis. We count 18 central banks as increasing their degree of transparency over the period, compared to six (Colombia, Jordan, Malawi, Sri Lanka , United Kingdom and Vanuatu) as becoming less transparent. Because the UK changed its objective to price stability and financial stability in 2009 versus price stability previously, we deduct 0.5 from its political transparency rating. ${ }^{21)}$ Sri Lanka, Jordan and Malawi receive lower ratings in terms of policy transparency due to changes in how they announce and explain policy decisions. Vanuatu receives lower marks for operational transparency, Colombia for economic and procedural transparency. It does not appear, on balance, that the financial crisis reversed the overall movement in the direction of greater central bank transparency, although -

on its relatively transparent small economies causes South East Asia to drop down. Either way, the lowest levels of transparency, starting from the bottom, are those of Middle Africa, Polynesia and Southern Asia no surprises here.

21) Our transparency index focuses on the transparency of monetary policy and its formulation, as in previous studies, and not also the transparency of micro- and macro-prudential policies, which are additional responsibilities of some central banks but not others (making it difficult to do consistent comparisons across central banks). However, when a central bank has a mandate for financial stability, this may make it more difficult for it to be as straightforward and transparent about its monetary policy strategies and objectives (as has frequently been argued in the literature). Thus, while we are concerned with the transparency of monetary policy per se, we have to take into account whether the central bank also has financial stability responsibilities. 
Figure 3: Trends in Transparency by Level of Economic Development (Weighted)

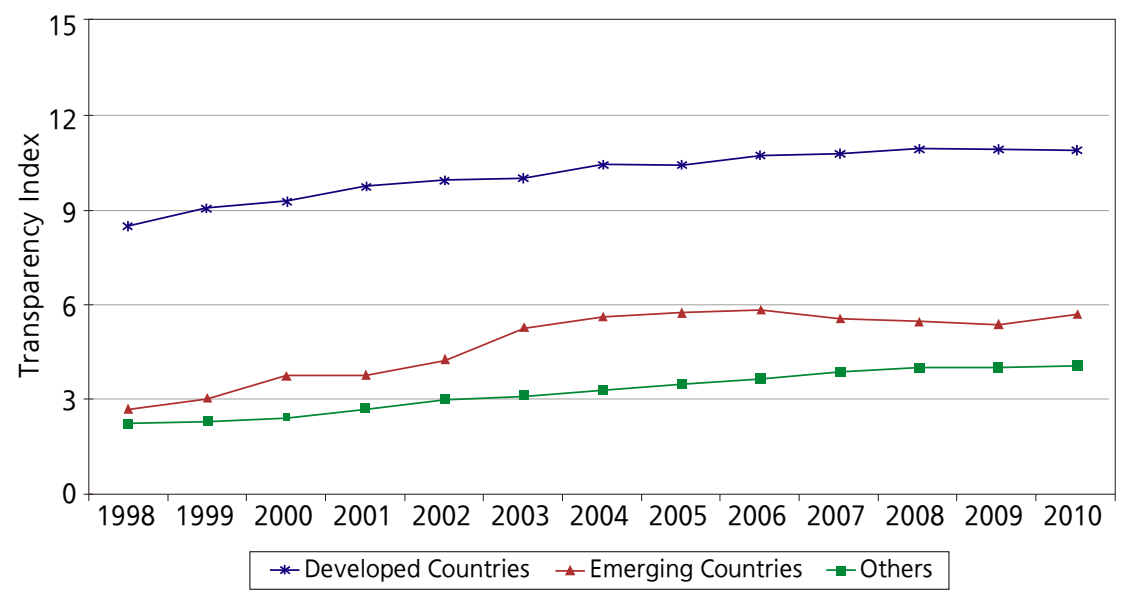

unlike earlier periods, a non-negligible number of countries buck the trend. It is sometimes argued that excessive transparency about, inter alia, problems in the financial system can be counterproductive (by provoking self-fulfilling bank runs etc.). If so, such concerns have not obviously reversed the trend toward greater transparency regarding the objectives and conduct of monetary policy, our concern here.

Figure 3 shows transparency by level of economic development.22) Not surprisingly, central banks in the advanced countries are more transparent than central banks in emerging markets (defined as middle-income countries with significant links to international financial markets), which in turn are more transparent than central banks in developing countries.23) We see an upward trend over time in all three categories of economies until 2006. In the case of emerging markets, this is in contrast to Crowe and Meade, who find no increase between 1998 and 2006; it is precisely in this period and subgroup of economies that our data show the most dramatic increase in the level of transparency.24)

22) Again, based on weighted averages.

23) We adopt the Dow-Jones classification of emerging markets throughout.

24) Siklos (2011) reports conclusions similar to ours. Note that no countries moved between emergingmarket and developing country status over the period according to our categorization. 
Strikingly, while transparency continues to trend upward in both the advanced and developing countries, the same emerging markets that made the most dramatic strides through 2006 (the terminal date of our earlier study) appear to give back some ground thereafter. This reflects somewhat lower rates for a number of larger emerging markets (Brazil and China in 2007, Brazil, Colombia and Poland in 2008).25)

Table 4: Determinants of Transparency, 1998-2010 Averages ${ }^{122) 3)}$

\begin{tabular}{|c|c|c|c|c|c|c|c|}
\hline & 1 & $\|$ & III & IV & V & VI & VII \\
\hline Constant & $\begin{array}{c}1.41 \\
(0.57)\end{array}$ & $\begin{array}{l}-5.20^{*} \\
(-2.43)\end{array}$ & $\begin{array}{l}-1.17 \\
(-0.67)\end{array}$ & $\begin{array}{c}4.49 \\
(1.68)\end{array}$ & $\begin{array}{l}-2.87 \\
(-1.45)\end{array}$ & $\begin{array}{l}-7.33^{*} \\
(-3.86)\end{array}$ & $\begin{array}{l}-2.80 \\
(-1.49)\end{array}$ \\
\hline Past Inflation & $\begin{array}{l}8.23^{*} \\
(3.16)\end{array}$ & $\begin{array}{c}4.16 \\
(1.32)\end{array}$ & $\begin{array}{c}5.81^{*} \\
(2.16)\end{array}$ & $\begin{array}{l}9.71^{*} \\
(4.47)\end{array}$ & $\begin{array}{c}-0.55 \\
(-0.18)\end{array}$ & $\begin{array}{c}4.62 \\
(1.48)\end{array}$ & $\begin{array}{c}-1.28 \\
(-0.35)\end{array}$ \\
\hline Openness & $\begin{array}{l}-0.01^{*} \\
(-3.51)\end{array}$ & $\begin{array}{l}-0.01^{*} \\
(-2.95)\end{array}$ & $\begin{array}{l}-0.01^{*} \\
(-2.23)\end{array}$ & $\begin{array}{l}-0.01^{*} \\
(-3.00)\end{array}$ & $\begin{array}{l}-0.00 \\
(-1.07)\end{array}$ & $\begin{array}{l}-0.01^{*} \\
(-3.09)\end{array}$ & $\begin{array}{c}-0.00 \\
(-0.77)\end{array}$ \\
\hline Financial Depth & $\begin{array}{c}0.01 \\
(1.13)\end{array}$ & $\begin{array}{c}0.01^{*} \\
(2.06)\end{array}$ & $\begin{array}{l}0.01^{*} \\
(2.14)\end{array}$ & $\begin{array}{c}0.00 \\
(0.63)\end{array}$ & $\begin{array}{c}0.01 \\
(1.18)\end{array}$ & $\begin{array}{c}0.01^{*} \\
(2.06)\end{array}$ & $\begin{array}{c}0.01 \\
(0.97)\end{array}$ \\
\hline GDP per Capita & $\begin{array}{c}0.38 \\
(1.25)\end{array}$ & $\begin{array}{l}1.13^{*} \\
(4.12)\end{array}$ & $\begin{array}{l}0.64^{*} \\
(3.02)\end{array}$ & $\begin{array}{c}0.00 \\
(0.00)\end{array}$ & $\begin{array}{l}0.81^{*} \\
(2.98)\end{array}$ & $\begin{array}{c}1.14^{*} \\
(5.32)\end{array}$ & $\begin{array}{c}0.83^{*} \\
(3.55)\end{array}$ \\
\hline Rule of Law & $\begin{array}{c}1.87^{*} \\
(3.95)\end{array}$ & & & & & & \\
\hline Political Stability & & $\begin{array}{c}0.17 \\
(0.44)\end{array}$ & & & & & \\
\hline Voice and Accountability & & & $\begin{array}{c}1.78^{*} \\
(6.09)\end{array}$ & & & & \\
\hline Government Efficiency & & & & $\begin{array}{l}2.67^{*} \\
(5.23)\end{array}$ & & & \\
\hline Democracy & & & & & $\begin{array}{l}0.17^{*} \\
(2.66)\end{array}$ & & \\
\hline Autocracy & & & & & & $\begin{array}{l}-0.13^{*} \\
(-2.24)\end{array}$ & \\
\hline Polity & & & & & & & $\begin{array}{c}0.17^{*} \\
(4.61)\end{array}$ \\
\hline R-Squared & 0.44 & 0.32 & 0.52 & 0.52 & 0.42 & 0.38 & 0.50 \\
\hline
\end{tabular}

Notes : 1) * denotes significance at $5 \%$.

2) t-statistics in parentheses.

3) The definition of independent variables are as follows: Past inflation is the logarithmic value of 1 plus the lagged inflation rate; openness is the share of the sum of exports and imports to GDP; financial depth is the ratio of M2 to GDP; GDP per capita is the logarithm of constant GDP per capita; rule of law, political stability, voice and accountability and government efficiency are from Governance Indicators Database; and democracy, autocracy and Polity are taken from Polity Database.

25) The People's Bank of China announced numerical forecasts before 2007 but not after. Brazil did not publish quarterly inflation reports starting from 2007 (they published all the reports for the period of 2007-2011 in July 2011). Poland changed the frequency of its inflation reports and inflation and output forecast announcements from 4 times a year to 3 times a year starting from 2008. Likewise Columbia changed the frequency of inflation reports from 4 times a year to 3 times a year starting from 2008. 
Table 5: Determinants of Transparency, Panel Fixed Effects ${ }^{1 / 2) 3)}$

\begin{tabular}{|c|c|c|c|c|c|c|c|c|}
\hline & 1 & $\|$ & III & IV & V & $\mathrm{VI}$ & VII & VIII \\
\hline Constant & $\begin{array}{l}-3.08 \\
(-0.01)\end{array}$ & $\begin{array}{c}-3.99 \\
(-0.01)\end{array}$ & $\begin{array}{l}-2.24 \\
(-0.01)\end{array}$ & $\begin{array}{l}-3.17 \\
(-0.01)\end{array}$ & $\begin{array}{l}-1.04 \\
(-0.02)\end{array}$ & $\begin{array}{l}-3.28 \\
(-0.01)\end{array}$ & $\begin{array}{l}-2.74 \\
(-0.01)\end{array}$ & $\begin{array}{l}-3.07 \\
(-0.01)\end{array}$ \\
\hline Past Inflation & $\begin{array}{l}-0.60 \\
(-1.27)\end{array}$ & $\begin{array}{l}-0.56 \\
(-1.20)\end{array}$ & $\begin{array}{l}-0.53 \\
(-1.13)\end{array}$ & $\begin{array}{l}-0.60 \\
(-1.26)\end{array}$ & $\begin{array}{l}-0.48 \\
(-1.02)\end{array}$ & $\begin{array}{l}-0.61 \\
(-1.35)\end{array}$ & $\begin{array}{l}-0.65 \\
(-1.44)\end{array}$ & $\begin{array}{l}-0.62 \\
(-1.38)\end{array}$ \\
\hline Openness & $\begin{array}{l}-0.01^{*} \\
(-3.24)\end{array}$ & $\begin{array}{l}-0.01^{*} \\
(-2.93)\end{array}$ & $\begin{array}{l}-0.01^{*} \\
(-3.31)\end{array}$ & $\begin{array}{l}-0.01^{*} \\
(-3.23)\end{array}$ & $\begin{array}{l}-0.01^{*} \\
(-3.81)\end{array}$ & $\begin{array}{c}-0.00 \\
(-1.82)\end{array}$ & $\begin{array}{l}-0.01^{*} \\
(-2.92)\end{array}$ & $\begin{array}{l}-0.00^{*} \\
(-2.13)\end{array}$ \\
\hline Financial Depth & $\begin{array}{l}0.03^{*} \\
(6.76)\end{array}$ & $\begin{array}{l}0.03^{*} \\
(6.66)\end{array}$ & $\begin{array}{l}0.03^{*} \\
(6.58)\end{array}$ & $\begin{array}{l}0.03^{*} \\
(6.77)\end{array}$ & $\begin{array}{l}0.03^{*} \\
(6.82)\end{array}$ & $\begin{array}{l}0.02^{*} \\
(5.75)\end{array}$ & $\begin{array}{l}0.02^{*} \\
(5.61)\end{array}$ & $\begin{array}{l}0.02^{*} \\
(5.70)\end{array}$ \\
\hline GDP per Capita & $\begin{array}{l}0.82^{*} \\
(6.99)\end{array}$ & $\begin{array}{l}0.92^{*} \\
(7.81)\end{array}$ & $\begin{array}{l}0.73^{*} \\
(6.63)\end{array}$ & $\begin{array}{l}0.83^{*} \\
(6.82)\end{array}$ & $\begin{array}{l}0.59^{*} \\
(4.96)\end{array}$ & $\begin{array}{l}0.66^{*} \\
(6.02)\end{array}$ & $\begin{array}{l}0.90^{*} \\
(8.40)\end{array}$ & $\begin{array}{l}0.75^{*} \\
(6.99)\end{array}$ \\
\hline Rule of Law & $\begin{array}{l}-0.11 \\
(0.85)\end{array}$ & & & & & & & \\
\hline Political Stability & & $\begin{array}{l}-0.31^{*} \\
(-2.78)\end{array}$ & & & & & & \\
\hline Voice and Accountability & & & $\begin{array}{c}0.21 \\
(1.78)\end{array}$ & & & & & \\
\hline Government Efficiency & & & & $\begin{array}{c}-0.12 \\
(-0.90)\end{array}$ & & & & \\
\hline Regulatory Quality & & & & & $\begin{array}{l}0.48^{*} \\
(3.46)\end{array}$ & & & \\
\hline Democracy & & & & & & $\begin{array}{l}0.29^{*} \\
(9.29)\end{array}$ & & \\
\hline Autocracy & & & & & & & $\begin{array}{l}-0.41^{*} \\
(-9.30)\end{array}$ & \\
\hline Polity & & & & & & & & $\begin{array}{l}0.19^{*} \\
(9.85)\end{array}$ \\
\hline Haussman test & $18.18^{*}$ & $11.01^{*}$ & $28.03^{*}$ & $26.85^{*}$ & $26.63^{*}$ & $11.91^{*}$ & 9.23 & 10.00 \\
\hline $\mathrm{R}$-Squared & 0.95 & 0.95 & 0.95 & 0.95 & 0.95 & 0.96 & 0.96 & 0.96 \\
\hline
\end{tabular}

Notes : 1) * denotes significance at $5 \%$.

2) t-statistics in parentheses.

3) The definition of independent variables are as follows: Past inflation is the logarithmic value of 1 lagged inflation; openness is the share of the sum of exports and imports to GDP; financial depth is the ratio of M2 to GDP; GDP per capita is the logarithm of constant GDP per capita; rule of law, political stability, voice and accountability and government efficiency are from Governance Indicators Database; and democracy, autocracy and Polity are taken from Polity Database.

Tables 4-5 update our earlier regressions on the determinants of transparency. Table 4 presents the cross-section results, with all variables averaged over the 19982010 period. Evidently, countries with higher per capita incomes, deeper financial 
markets, more open economies, and stronger political institutions have more transparent central banks. A new result here is the positive association between past inflation and current transparency. However, the inflation variable is not significant in all specifications; it is correlated with various dimensions of the political regime (columns V-VII), making it hard to identify its effects. ${ }^{26)}$

Table 5 reports the analogous panel estimates, with country effects included in all columns. ${ }^{27)}$ Since these results eliminate time-invariant country-specific effects, they can be interpreted as analyzing the determinants of changes in transparency over time. Here the positive effects of higher per capita incomes, deeper financial markets, more economic openness and stronger political institutions come through even more clearly than before. In contrast, past inflation is uniformly insignificant, reinforcing our earlier skepticism about the robustness of this variable.

Some previous studies, including our own, have suggested that transparency becomes more important as a mechanism of monetary-policy accountability when countries adopt a more flexible exchange rate and success at maintaining a peg no longer suffices for verifying the ability of the central bank to attain its monetarypolicy goals. In Appendix Table B2 we add a measure of the flexibility of the exchange rate regime. This index is based on the IMF coarse-classification data provided by Ilzetzki, Reinhart and Rogoff (2008) and takes the score 1 to 6 where a higher score indicates a more flexible exchange rate regime. Data on the exchange rate regime are available only through 2007, making for a shorter sample, which is why we relegate these results to an appendix. They confirm the presumption that countries with more flexible exchange rate regimes also tend to have more transparent central banks. Otherwise, these alternative estimates are broadly consistent with those in the text.28)

Table 6 updates our earlier analysis of the effects of transparency on inflation

26) Some recent literature has suggested the existence of a positive relationship between inflation and democracy, especially in the Latin American context (see e.g. Haggard and Kaufman 1995).

27) The variables used here are stationary and cointegrated according to the standard Augmented DickeyFuller tests.

28) Estimates on panel data including country fixed effects are again consistent with the just-mentioned results, although the exchange-rate-regime variable is not consistently significant at the same high level of confidence. 
variability, defined as the standard deviation of monthly inflation in a given year. We use the independent variables in Tables 4-5 as instruments for transparency in Tables 6 and include as additional determinants of inflation variability measures of openness, financial depth and past inflation. According to Table 6, more open economies have less variable inflation, while countries with a past history of inflation experience more nominal variability. Central bank transparency consistently enters with a negative coefficient that is significant at the 95 per cent confidence level or higher. Both the point estimates and standard errors are similar to those in our earlier paper where we were limited to data through 2006.29)

\section{Table 6: Effect of Transparency on Inflation Variability ${ }^{1 / 2) 3)}$ (GMM, full sample)}

\begin{tabular}{l|c|c|c|c|c|c|c|}
\hline & I & II & III & IV & V & VI \\
\hline Constant & $\begin{array}{c}4.08^{*} \\
(5.78)\end{array}$ & $\begin{array}{c}8.37^{*} \\
(4.86)\end{array}$ & $\begin{array}{c}5.49^{*} \\
(5.47)\end{array}$ & $\begin{array}{c}0.72^{*} \\
(2.40)\end{array}$ & $\begin{array}{c}7.40^{*} \\
(4.66)\end{array}$ & $\begin{array}{c}5.18^{*} \\
(3.73)\end{array}$ \\
\hline Transparency Index & $\begin{array}{l}-0.36^{*} \\
(-3.53)\end{array}$ & $\begin{array}{c}-0.43^{*} \\
(-4.23)\end{array}$ & $\begin{array}{l}-0.18^{*} \\
(-2.25)\end{array}$ & $\begin{array}{c}-0.10^{*} \\
(-1.79)\end{array}$ & $\begin{array}{c}-0.33^{*} \\
(-2.91)\end{array}$ & $\begin{array}{c}-0.24^{*} \\
(-2.47)\end{array}$ \\
\hline Openness & & $-0.05^{*}$ & & & $-0.03^{*}$ & $-0.02^{*}$ \\
& & $(-3.55)$ & & & $(-2.76)$ & $(-2.77)$ \\
\hline Financial Depth & & & $-0.05^{*}$ & & -0.01 & -0.01 \\
& & & $(-3.93)$ & & $(-0.97)$ & $(-0.65)$ \\
\hline Past Inflation & & & & $24.71^{*}$ & & $7.77^{*}$ \\
& & & & $(9.89)$ & & $(2.00)$ \\
\hline Durbin-Watson statistics & 0.68 & 0.57 & 0.67 & 0.96 & 0.61 & 0.70 \\
\hline J-statistics & 0.00 & 0.05 & 0.00 & 0.00 & 1.67 & 1.97 \\
\hline Number of observations & 1109 & 1048 & 1056 & 1076 & 1016 & 993 \\
\hline Sum of Sq. Res. & 29948 & 36498 & 29955 & 13774 & 33182 & 23071 \\
\hline
\end{tabular}

Notes : 1) * denotes significance at $10 \%$.

2) t-statistics in parentheses based on White cross section standard errors (degrees of freedom corrected).

3) Dependent variable is inflation variability, which is the standard deviation of the inflation rate for the 12 months of the calendar year. The definitions of independent variables are as follows: Past inflation is the logarithmic value of 1 plus the lagged inflation rate; openness is the share of the sum of exports and imports to GDP; financial depth is the ratio of M2 to GDP. The instrumental variables are rule of law, political stability, accountability, government efficiency and regulatory quality which are taken from Governance Indicators Database and democracy, taken from Polity database.

29) Greater transparency is also associated with lower levels of inflation persistence, but insignificantly so in all specifications (in contrast to our earlier results, where we found significant effects). 
Table 7: Effect of Transparency on Inflation (GMM, full sample) ${ }^{1223)}$

\begin{tabular}{l|c|c|c|c|c|c|c|} 
& I & II & III & IV & V & VI \\
\hline Constant & $\begin{array}{l}16.95^{*} \\
\text { (15.01) }\end{array}$ & $\begin{array}{c}-21.84^{*} \\
(10.34)\end{array}$ & $\begin{array}{c}15.83^{*} \\
(11.15)\end{array}$ & $\begin{array}{c}1.74 \\
(0.95)\end{array}$ & $\begin{array}{c}20.13^{*} \\
(8.87)\end{array}$ & $\begin{array}{c}-0.31 \\
(-0.06)\end{array}$ \\
\hline Transparency Index & $-2.25^{*}$ & $-1.38^{*}$ & $-0.60^{*}$ & -0.19 & $-1.15^{*}$ & -0.26 \\
& $(-9.02)$ & $(-7.86)$ & $(-2.86)$ & $(-0.86)$ & $(-2.74)$ & $(-1.42)$ \\
\hline Openness & & $-0.10^{*}$ & & & $-0.08^{*}$ & $-0.03^{*}$ \\
& & $(-5.92)$ & & & $(-4.52)$ & $(-1.77)$ \\
\hline Financial Depth & & & $-0.11^{*}$ & & -0.02 & 0.06 \\
& & & $(-8.05)$ & & $(-0.62)$ & $(1.10)$ \\
\hline Past Inflation & & & & $0.81^{*}$ & & $1.05^{*}$ \\
& & & & $(7.87)$ & & $(3.01)$ \\
\hline Durbin-Watson stat & 0.33 & 0.33 & 0.41 & 1.78 & 0.35 & 1.56 \\
\hline J-statistics & 0.00 & 0.00 & 0.00 & 0.19 & 15.95 & 0.00 \\
\hline Number of observations & 1450 & 1332 & 1345 & 1324 & 1282 & 1203 \\
\hline Sum of Sq. Res. & 200373 & 193567 & 150602 & 90363 & 172736 & 128071 \\
\hline
\end{tabular}

Notes : 1) * denotes significance at $10 \%$.

2) t-statistics in parentheses, based on White cross section standard errors (degrees of freedom corrected).

3) Dependent variable is inflation. The definitions of independent variables are as follows: Past inflation is the logarithmic value of 1 plus the lagged inflation rate; openness is the share of the sum of exports and imports to GDP; financial depth is the ratio of M2 to GDP. The instrumental variables are rule of law, political stability, accountability, government efficiency and regulatory quality which are taken from Governance Indicators Database and democracy, taken from Polity database.

Table 7 reports the analogous results for the level of inflation. Greater transparency is associated with lower average levels of inflation, although levels of statistical significance are less consistent than in Table 6 for inflation variability. 


\section{Measures of Central Bank Independence}

Table 8 reports measures of central bank independence in 2010 on four alternative definitions. ${ }^{30)}$ The first two definitions follow Cukierman, Webb and Neyapti (1992, CWN henceforth) but for the period 1998-2010.31) CWN base their measure of legal independence on 16 criteria coded on a 0 to 1 scale (lowest and highest levels of independence, respectively). These reflect the independence of the chief executive officer (CEO) of the central bank, its independence in policy formulation, its objective or mandate, and the stringency of limits on its lending to public sector.

They then aggregate these 16 criteria into 8 as follows.

1. Four variables concerned with the independence of the CEO are aggregated with equal weights, i.e. $(1 \mathrm{a}+1 \mathrm{~b}+1 \mathrm{c}+1 \mathrm{~d}) / 4$;

2. The three policy formulation variables, namely $2 \mathrm{a}, 2 \mathrm{~b}$ and $2 \mathrm{c}$, are aggregated (with weights $0.5,0.25,0.25$, respectively) as one variable;

3. Objectives criterion, 3 .

4. Advances criterion under limits on lending;

5. Securitized lending under limits on lending;

6. Terms of Lending criterion under limits on lending;

7. Potential borrowers from the bank criterion under limits on lending

8. Four criteria, 4e, 4f, 4g, $4 \mathrm{~h}$ on limits on lending are aggregated to one by using equal weights, namely $(4 \mathrm{e}+4 \mathrm{f}+4 \mathrm{~g}+4 \mathrm{~h}) / 4$

Table 8: Comparison of Different Measures of Independence in 2010

\begin{tabular}{c|l|c|c|c|c} 
& & LVAU & LVAW & CBIU & CBIW \\
\hline 1 & Krgyz Republic & 0.89 & 0.88 & 0.86 & 0.83 \\
\hline 2 & Latvia & 0.88 & 0.87 & 0.86 & 0.83 \\
\hline 3 & EU & 0.85 & 0.84 & 0.84 & 0.81 \\
\hline 4 & Lithuania & 0.85 & 0.84 & 0.81 & 0.79 \\
\hline
\end{tabular}

30) The sample is smaller for independence for transparency, since our work on independence is recent and we were not able to fill in as many missing observations as in our ongoing work on transparency. As for transparency we gather central bank independence index from central bank law of the countries that are in affect for the period 1998-2010. We accessed copies of the laws using central bank websites, the IMF Law Library and the UC Berkeley Law Library.

31) Where their criteria are described in Appendix A. 


\begin{tabular}{|c|c|c|c|c|c|}
\hline & & LVAU & LVAW & CBIU & CBIW \\
\hline 5 & Romania & 0.83 & 0.82 & 0.81 & 0.79 \\
\hline 6 & Estonia & 0.85 & 0.84 & 0.80 & 0.79 \\
\hline 7 & Armenia & 0.86 & 0.85 & 0.79 & 0.77 \\
\hline 8 & Sweden & 0.80 & 0.78 & 0.78 & 0.77 \\
\hline 9 & Hungary & 0.88 & 0.87 & 0.78 & 0.77 \\
\hline 10 & Macedonia & 0.82 & 0.81 & 0.76 & 0.74 \\
\hline 11 & Indonesia & 0.80 & 0.77 & 0.74 & 0.73 \\
\hline 12 & Croatia & 0.80 & 0.79 & 0.75 & 0.73 \\
\hline 13 & Bosnia and Herzigova & 0.86 & 0.84 & 0.72 & 0.72 \\
\hline 14 & Iceland & 0.71 & 0.67 & 0.69 & 0.69 \\
\hline 15 & Iraq & 0.75 & 0.74 & 0.71 & 0.69 \\
\hline 16 & Chile & 0.78 & 0.76 & 0.72 & 0.69 \\
\hline 17 & Moldova & 0.73 & 0.71 & 0.68 & 0.68 \\
\hline 18 & Sierra Leone & 0.72 & 0.69 & 0.67 & 0.67 \\
\hline 19 & El Salvador & 0.78 & 0.75 & 0.66 & 0.67 \\
\hline 20 & Kenya & 0.68 & 0.65 & 0.67 & 0.67 \\
\hline 21 & Azarbaijan & 0.65 & 0.65 & 0.62 & 0.65 \\
\hline 22 & Lesotho & 0.71 & 0.69 & 0.65 & 0.64 \\
\hline 23 & Venezuela & 0.73 & 0.71 & 0.65 & 0.64 \\
\hline 24 & Czeck & 0.68 & 0.66 & 0.66 & 0.64 \\
\hline 25 & Cambodia & 0.67 & 0.65 & 0.64 & 0.64 \\
\hline 26 & Mexico & 0.66 & 0.65 & 0.65 & 0.63 \\
\hline 27 & Albania & 0.67 & 0.65 & 0.64 & 0.62 \\
\hline 28 & Russia & 0.77 & 0.77 & 0.62 & 0.61 \\
\hline 29 & Turkey & 0.73 & 0.71 & 0.62 & 0.60 \\
\hline 30 & Sri Lanka & 0.68 & 0.66 & 0.63 & 0.60 \\
\hline 31 & Bulgaria & 0.71 & 0.70 & 0.60 & 0.58 \\
\hline 32 & Peru & 0.56 & 0.58 & 0.53 & 0.56 \\
\hline 33 & Argentine & 0.60 & 0.60 & 0.57 & 0.56 \\
\hline 34 & Tanzania & 0.62 & 0.60 & 0.58 & 0.56 \\
\hline 35 & ECCB & 0.61 & 0.56 & 0.57 & 0.55 \\
\hline 36 & Georgia & 0.60 & 0.58 & 0.63 & 0.55 \\
\hline 37 & Papua New Guninea & 0.59 & 0.56 & 0.55 & 0.54 \\
\hline 38 & Mongolia & 0.59 & 0.58 & 0.54 & 0.53 \\
\hline 39 & Angola & 0.51 & 0.50 & 0.52 & 0.52 \\
\hline 40 & Israel & 0.56 & 0.54 & 0.54 & 0.52 \\
\hline 41 & Nigeria & 0.43 & 0.52 & 0.45 & 0.51 \\
\hline 42 & Guyana & 0.57 & 0.54 & 0.51 & 0.50 \\
\hline 43 & Malaysia & 0.57 & 0.54 & 0.52 & 0.49 \\
\hline 44 & Mauritius & 0.55 & 0.49 & 0.50 & 0.48 \\
\hline 45 & Yemen & 0.52 & 0.50 & 0.49 & 0.47 \\
\hline 46 & Norway & 0.56 & 0.54 & 0.50 & 0.47 \\
\hline 47 & China & 0.56 & 0.52 & 0.45 & 0.46 \\
\hline 48 & Tunisia & 0.54 & 0.50 & 0.49 & 0.46 \\
\hline 49 & Oman & 0.51 & 0.50 & 0.49 & 0.45 \\
\hline 50 & Canada & 0.46 & 0.48 & 0.43 & 0.43 \\
\hline
\end{tabular}




\begin{tabular}{|c|c|c|c|c|c|}
\hline & & LVAU & LVAW & CBIU & CBIW \\
\hline 51 & UAE & 0.46 & 0.48 & 0.42 & 0.42 \\
\hline 52 & Seychelles & 0.43 & 0.37 & 0.45 & 0.40 \\
\hline 53 & Malawi & 0.48 & 0.42 & 0.44 & 0.39 \\
\hline 54 & Bhutan & 0.45 & 0.45 & 0.43 & 0.39 \\
\hline 55 & Lao Republic & 0.47 & 0.39 & 0.44 & 0.39 \\
\hline 56 & Botswana & 0.46 & 0.40 & 0.41 & 0.38 \\
\hline 57 & Fiji & 0.41 & 0.39 & 0.37 & 0.37 \\
\hline 58 & Poland & 0.31 & 0.41 & 0.32 & 0.37 \\
\hline 59 & Solomon Islands & 0.38 & 0.42 & 0.36 & 0.37 \\
\hline 60 & Zambia & 0.41 & 0.38 & 0.39 & 0.36 \\
\hline 61 & Namibia & 0.33 & 0.36 & 0.32 & 0.36 \\
\hline 62 & Japan & 0.35 & 0.35 & 0.38 & 0.35 \\
\hline 63 & Mozambique & 0.36 & 0.35 & 0.38 & 0.34 \\
\hline 64 & Jordan & 0.40 & 0.40 & 0.36 & 0.33 \\
\hline 65 & Korea & 0.32 & 0.32 & 0.33 & 0.32 \\
\hline 66 & Somali & 0.33 & 0.36 & 0.33 & 0.32 \\
\hline 67 & Vanuatu & 0.39 & 0.32 & 0.34 & 0.30 \\
\hline 68 & Philippines & 0.21 & 0.29 & 0.25 & 0.29 \\
\hline 69 & Columbia & 0.34 & 0.33 & 0.33 & 0.29 \\
\hline 70 & Uganda & 0.39 & 0.37 & 0.34 & 0.28 \\
\hline 71 & Cuba & 0.32 & 0.28 & 0.31 & 0.27 \\
\hline 72 & New Zealand & 0.25 & 0.33 & 0.23 & 0.26 \\
\hline 73 & Bahamas & 0.28 & 0.27 & 0.25 & 0.26 \\
\hline 74 & Thailand & 0.24 & 0.29 & 0.24 & 0.26 \\
\hline 75 & Belize & 0.33 & 0.28 & 0.29 & 0.25 \\
\hline 76 & Syria & 0.32 & 0.27 & 0.29 & 0.25 \\
\hline 77 & Trinidad and Tobaggo & 0.27 & 0.28 & 0.27 & 0.25 \\
\hline 78 & Belarus & 0.21 & 0.29 & 0.23 & 0.24 \\
\hline 79 & UK & 0.17 & 0.24 & 0.21 & 0.23 \\
\hline 80 & Jamaica & 0.24 & 0.25 & 0.22 & 0.22 \\
\hline 81 & Samoa & 0.28 & 0.24 & 0.25 & 0.20 \\
\hline 82 & US & 0.12 & 0.17 & 0.18 & 0.18 \\
\hline 83 & Australia & 0.14 & 0.19 & 0.14 & 0.17 \\
\hline 84 & Barbados & 0.19 & 0.18 & 0.18 & 0.17 \\
\hline 85 & Maldives & 0.14 & 0.19 & 0.16 & 0.17 \\
\hline 86 & South Africa & 0.20 & 0.19 & 0.19 & 0.15 \\
\hline 87 & Saudi Arabia & 0.10 & 0.14 & 0.09 & 0.12 \\
\hline 88 & Singapore & 0.10 & 0.14 & 0.09 & 0.11 \\
\hline 89 & India & 0.13 & 0.09 & 0.15 & 0.10 \\
\hline
\end{tabular}

From these 8 aggregated variables two indices are computed. LVAU is the unweigted average of the 8 aggregated variables whereas LVAW is the weighted average where the weights are given in Appendix A.

For our two additional summary measures of central bank independence, we aug- 
ment Cukierman, Webb and Neyapti's criteria by adding other aspects of central bank independence emphasized in the subsequent literature. We added measures of limits on the reappointment of the CEO, measures of provisions affecting (re) appointment of other board members similar to those affecting the CEO, restrictions on government representation on the board, and intervention of the government in exchange rate policy formulation.32) The importance of rules governing the appointment and dismissal of entire central bank board, as opposed to just the governor, and restrictions on government representation on the board were suggested by Bade and Parkin (1982), Grilli, Masciandro and Tabellini (1991), Eijffinger and Schaling (1993) and Jacome and Vazquez (2008). Government intervention in the formulation and conduct of foreign exchange policy is emphasized by Jacome and Vazquez (2008). The two additional measures are denoted Central Bank Independence Unweighted (CBIU) and Central Bank Independence Index Weighted (CBIW). ${ }^{33)}$

\section{Trends in Central Bank Independence}

The most independent central banks are those of the Kyrgyz Republic, Latvia, Hungary, Armenia, and Bosnia and Herzegovina (in descending order), according to our LVAU and LVAW indices, and the Krgyz Republic, Latvia and the Euro Zone according to CBIU and CBIW. India, Saudi Arabia, Singapore and the United States are the countries with the least independent central banks according to LVAU and

32) The resulting 24 criteria are first aggregated into 9 criteria as follows. 1) The five variables regarding appointment of the CEO are aggregated into one equal weights; 2) the four variables under policy formulationare aggregated into one using equal weights,; 3) the objectives criterion stands on its own as number 3, 4-7) the first four criteria on limits on lending are each treated as a separate variable, 8) the last four criteria on limits on lending are aggregated into a single variable using equal weights; 9) the criteria regarding board members is treated as a single variable. From these 9 aggregated variables two indices are computed. CBIU is the unweighted average of the 9 aggregated variables, CBIW the corresponding weighted average. The detailed criteria list and weights used in constructing CBIW are described in Appendix A.

33) The four measures of central bank independence are quite highly correlated with one another, as shown in Appendix B. 
LVAW. The Monetary Authority of Singapore and Saudi Arabian Monetary Agency are not subject to statutory limits on lending to the government, and their policy formulation is not entirely independent of government. The Reserve Bank of India, for its part, receives low scores for (the absence of) restrictions on the appointment of the governor, independence of policy formulation, and possession of an independent objective. The Federal Reserve is similarly not subject to statutory restrictions on its lending to the government.

Table 9 and Table 10 present unweighted and weighted regional independence indices, respectively. They show that, on average, Europe has the most independent central banks, Oceania and Americas the least.

Table 9: Independence (CBIW) by Country and Region (Unweighted)

\begin{tabular}{|c|c|c|c|c|c|c|c|c|c|c|c|c|c|}
\hline & 1998 & 1999 & 2000 & 2001 & 2002 & 2003 & 2004 & 2005 & 2006 & 2007 & 2008 & 2009 & 2010 \\
\hline Africa & 0.43 & 0.43 & 0.47 & 0.47 & 0.47 & 0.47 & 0.47 & 0.47 & 0.47 & 0.47 & 0.48 & 0.48 & 0.48 \\
\hline Eastern Africa & 0.40 & 0.40 & 0.39 & 0.39 & 0.39 & 0.39 & 0.39 & 0.39 & 0.41 & 0.41 & 0.42 & 0.44 & 0.44 \\
\hline Kenya & 0.67 & .67 & 0.67 & 0.67 & 0.67 & 0.67 & 0.67 & 0.67 & 0.67 & 0.67 & 0.67 & 0.67 & 0.67 \\
\hline Malawi & 0.39 & 0.39 & .39 & 0.39 & 0.39 & 0.39 & 0.39 & 0.39 & 0.39 & 0.39 & 0.39 & 0.39 & .39 \\
\hline Mauritius & 0.32 & 0.32 & 0.32 & 0.32 & 0.32 & 0.32 & 0.39 & 0.39 & 0.39 & 0.43 & 0.48 & 0.48 & 0.48 \\
\hline Mozambique & 0.34 & .34 & .34 & 0.34 & 0.34 & 0.34 & 0.34 & 0.34 & 0.34 & 0.34 & .34 & 0.34 & 0.34 \\
\hline Seychelles & .26 & .26 & .26 & 0.26 & 0.26 & 0.26 & 0.26 & 0.26 & 0.26 & 0.26 & .26 & 0.40 & 0.40 \\
\hline $\operatorname{Tan}$ & 46 & 0.46 & .46 & 0.46 & 0.46 & 46 & 0.46 & 0.46 & 0.56 & .56 & 56 & 56 & .56 \\
\hline Uganda & & & 0.28 & 0.28 & 0.28 & 0.28 & 0.28 & 0.28 & 0.28 & 0.28 & 0.28 & 0.28 & .28 \\
\hline Zambia & 36 & 0.36 & 0.36 & 0.36 & 0.36 & .36 & 0.36 & 0.36 & 0.36 & 0.36 & 36 & 36 & .36 \\
\hline Northern Africa & & & 0.46 & 0.46 & 0.46 & 0.46 & 0.46 & 0.46 & 0.46 & 0.46 & 0.46 & 0.46 & 0.46 \\
\hline Tunisia & & & 0.46 & 0.46 & 0.46 & 0.46 & 0.46 & 0.46 & 0.46 & 0.46 & 0.46 & 0.46 & 0.46 \\
\hline Middle $A f$ & 0.52 & 0.52 & 0.52 & 0.52 & 0.52 & 0.52 & 0.52 & 0.52 & 0.52 & 0.52 & 0.52 & 0.52 & 0.52 \\
\hline Angola & 0.52 & 0.52 & 0.52 & 0.52 & 0.52 & 0.52 & 0.52 & 0.52 & 0.52 & 0.52 & 0.52 & 0.52 & 0.52 \\
\hline Southern A & 0.30 & 0.30 & 0.38 & 0.38 & 0.38 & 0.38 & 0.38 & 0.38 & 0.38 & 0.38 & 0.38 & 0.38 & 0.38 \\
\hline Botswana & 0.38 & 0.38 & 0.38 & 0.38 & 0.38 & 0.38 & 0.38 & 0.38 & 0.38 & 0.38 & 0.38 & 0.38 & 0.38 \\
\hline Lesotho & & & 0.64 & 0.64 & 0.64 & 0.64 & 0.64 & 0.64 & 0.64 & 0.64 & 0.64 & 0.64 & 0.64 \\
\hline Namibia & 0.36 & 0.36 & 0.36 & 0.36 & 0.36 & 0.36 & 0.36 & 0.36 & 0.36 & 0.36 & 0.36 & 0.36 & 0.36 \\
\hline South Africa & 0.15 & 0.15 & 0.15 & 0.15 & 0.15 & 0.15 & 0.15 & 0.15 & 0.15 & 0.15 & 0.15 & 0.15 & 0.15 \\
\hline Western Africa & 0.58 & 0.58 & 0.58 & 0.58 & 0.58 & 0.58 & 0.58 & 0.58 & 0.58 & 0.59 & 0.59 & 0.59 & 0.59 \\
\hline Nigeria & 0.49 & 0.49 & 0.49 & 0.49 & 0.49 & 0.49 & 0.49 & 0.49 & 0.49 & .51 & .51 & .51 & .51 \\
\hline Sierra L & 0.67 & 0.67 & 0.67 & 0.67 & 0.67 & 0.67 & 0.67 & 0.67 & 0.67 & 0.67 & 0.67 & 0.67 & 0.67 \\
\hline Americas & 0.39 & 0.39 & 0.39 & 0.41 & 0.41 & 0.41 & 0.41 & 0.41 & 0.41 & .41 & 0.41 & .41 & 0.41 \\
\hline Latin A. \& Carib & 0.29 & 0.29 & 0.29 & 0.29 & 0.29 & 0.29 & 0.29 & 0.29 & 0.29 & 0.29 & 0.29 & 0.29 & 0.29 \\
\hline East Caribbean & 0.55 & 0.55 & 0.55 & 0.55 & 0.55 & 0.55 & 0.55 & 0.55 & 0.55 & 0.55 & 0.55 & 0.55 & 0.55 \\
\hline Bahamas & & & 0.26 & 0.26 & 0.26 & 0.26 & 0.26 & 0.26 & 0.26 & 0.26 & 0.26 & 0.26 & 0.26 \\
\hline Barbados & 0.17 & 0.17 & 0.17 & 0.17 & 0.17 & 0.17 & 0.17 & 0.17 & 0.17 & 0.17 & 0.17 & 0.17 & 0.17 \\
\hline Cuba & 0.27 & 0.27 & 0.27 & 0.27 & 0.27 & 0.27 & 0.27 & 0.27 & 0.27 & 0.27 & 0.27 & 0.27 & 0.27 \\
\hline Jamaica & 0.22 & 0.22 & 0.22 & 0.22 & 0.22 & 0.22 & 0.22 & 0.22 & 0.22 & 0.22 & 0.22 & 0.22 & 0.22 \\
\hline Trinidad and Toba & 0.25 & 0.25 & 0.25 & 0.25 & 0.25 & 0.25 & 0.25 & 0.25 & 0.25 & 0.25 & 0.25 & 0.25 & 0.25 \\
\hline Central America & 0.52 & 0.52 & 0.52 & 0.52 & 0.52 & 0.52 & 0.52 & 0.52 & 0.52 & 0.52 & 0.52 & 0.52 & 0.52 \\
\hline
\end{tabular}




\begin{tabular}{|c|c|c|c|c|c|c|c|c|c|c|c|c|c|}
\hline & 1998 & 1999 & 2000 & 2001 & 2002 & 2003 & 2004 & 2005 & 2006 & 2007 & 2008 & 2009 & 2010 \\
\hline Belize & 0.25 & 0.25 & 0.25 & 0.25 & 0.25 & 0.25 & 0.25 & 0.25 & 0.25 & 0.25 & 0.25 & 0.25 & 0.25 \\
\hline El Salvador & 0.67 & 0.67 & 67 & 0.67 & 0.67 & 0.67 & 0.67 & 0.67 & 0.67 & 0.67 & 0.67 & 0.67 & 0.67 \\
\hline Mexico & 0.63 & 0.63 & 0.63 & 0.63 & 0.63 & 0.63 & 0.63 & 0.63 & 0.63 & 0.63 & 0.63 & 0.63 & 0.63 \\
\hline South America & 0.47 & 0.47 & 0.47 & 0.55 & 0.54 & 0.54 & 0.54 & 0.54 & 0.54 & 0.54 & 0.54 & 0.54 & 0.54 \\
\hline Argentina & 0.62 & 0.62 & 0.62 & 0.62 & 0.56 & 0.56 & 0.56 & 0.56 & 0.56 & 0.56 & 0.56 & 0.56 & 0.56 \\
\hline Chile & 0.66 & 0.66 & 0.66 & 0.66 & 0.66 & 0.66 & 0.66 & 0.66 & 0.66 & 0.69 & 0.69 & 0.69 & 0.69 \\
\hline Colombia & 0.29 & 0.29 & 0.29 & 0.29 & 0.29 & 0.29 & 0.29 & 0.29 & 0.29 & 0.29 & .29 & .29 & .29 \\
\hline Guyana & 0.50 & 0.50 & 0.50 & 0.50 & 0.50 & 0.50 & 0.50 & 0.50 & 0.50 & 0.50 & 0.50 & 0.50 & 0.50 \\
\hline Peru & 0.56 & 0.56 & 0.56 & 0.56 & 0.56 & 0.56 & 0.56 & 0.56 & 0.56 & 0.56 & .56 & 0.56 & 0.56 \\
\hline Venezuela & 0.16 & 0.16 & 0.16 & 0.64 & 0.64 & 0.64 & 0.64 & 0.64 & 0.64 & 0.64 & 0.64 & 0.64 & 0.64 \\
\hline Northern America & 0.30 & 0.30 & 0.30 & 0.30 & 0.30 & 0.30 & 0.30 & 0.30 & 0.30 & 0.30 & 0.30 & 0.30 & 0.30 \\
\hline Canada & 0.43 & 0.43 & 0.43 & 0.43 & 0.43 & 0.43 & 0.43 & 0.43 & 0.43 & 0.43 & 0.43 & 0.43 & 0.43 \\
\hline United States of & 0.18 & 0.18 & 0.18 & 0.18 & 0.18 & 0.18 & 0.18 & 0.18 & 0.18 & 0.18 & 0.18 & 0.18 & 0.18 \\
\hline Oceania & 0.26 & 0.26 & 0.28 & 0.28 & 0.27 & 0.27 & 0.27 & 0.27 & 0.27 & 0.27 & 0.27 & 0.27 & 0.27 \\
\hline Australia & 0.24 & 0.24 & 0.24 & 0.24 & 0.22 & 0.22 & 0.22 & 0.22 & 0.22 & 0.22 & 0.22 & 0.22 & 0.22 \\
\hline Australia & 0.21 & 0.21 & 0.21 & 0.21 & 0.17 & 0.17 & 0.17 & 0.17 & 0.17 & 0.17 & 0.17 & 0.17 & 0.17 \\
\hline New Z & 0.26 & 0.26 & .26 & 0.26 & 0.26 & 0.26 & 0.26 & 0.26 & 0.26 & 0.26 & 0.26 & 0.26 & 0.26 \\
\hline Melanesia & 0.34 & 0.34 & 0.40 & 0.40 & 0.40 & 0.40 & 0.40 & 0.40 & 0.40 & 0.40 & 0.40 & 0.40 & 0.40 \\
\hline Fiji & 0.37 & 0.37 & 0.37 & 0.37 & 0.37 & 0.37 & 0.37 & 0.37 & 0.37 & 0.37 & 0.37 & 0.37 & 0.37 \\
\hline Papua New Guine & 0.31 & 0.31 & 0.54 & 0.54 & 0.54 & 0.54 & 0.54 & 0.54 & 0.54 & 0.54 & .54 & .54 & 0.54 \\
\hline Solomon Islands & 0.37 & 0.37 & 0.37 & 0.37 & 0.37 & 0.37 & 0.37 & 0.37 & 0.37 & 0.37 & 0.37 & 0.37 & 0.37 \\
\hline Va & 0.30 & 0.30 & 0.30 & 0.30 & 0.30 & 0.30 & 0.30 & 0.30 & 0.30 & 0.30 & 30 & .30 & .30 \\
\hline Polynesia & 0.20 & 0.20 & 0.20 & 0.20 & 0.20 & 0.20 & 0.20 & 0.20 & 0.20 & 0.20 & 0.20 & 0.20 & 0.20 \\
\hline Sar & 0.20 & & & & & & & & & & 20 & & \\
\hline Asia & 0.44 & 0.45 & 0.45 & 0.46 & 0.46 & 0.46 & 0.47 & 0.47 & 0.47 & 0.47 & 0.48 & 0.48 & 0.49 \\
\hline Central Asia & 0.83 & 0.83 & 0.83 & 0.83 & 0.83 & 0.83 & 0.83 & 0.83 & 0. & 0.83 & 83 & 83 & 83 \\
\hline Kyrgyzstan & 0.83 & 0.83 & 0.83 & 0.83 & 0.83 & 0.83 & 0.83 & 0.83 & 0.83 & 0.83 & 0.83 & 0.83 & 0.83 \\
\hline Eastern Asia & 0.41 & 0.41 & 0.41 & 0.41 & 0.41 & 0.41 & 0.41 & 0.41 & 0.41 & 0.41 & 0.41 & 0.41 & 0.41 \\
\hline China & 0.46 & 0.46 & 0.46 & 0.46 & 0.46 & 0.46 & 0.46 & 0.46 & 0.46 & 0.46 & 0.46 & 0.46 & 0.46 \\
\hline Korea & 0.32 & 0.32 & 0.32 & 0.32 & 0.32 & 0.32 & 0.32 & 0.32 & 0.32 & 0.32 & 0.32 & 0.32 & 0.32 \\
\hline Japan & 0.35 & 0.35 & 0.35 & 0.35 & 0.35 & 0.35 & 0.35 & 0.35 & 0.35 & 0.35 & 0.35 & 0.35 & 0.35 \\
\hline Mongolia & 0.53 & 0.53 & 0.53 & 0.53 & 0.53 & 0.53 & 0.53 & 0.53 & 0.53 & 0.53 & 0.53 & 0.53 & 0.53 \\
\hline Southern & 0.23 & 0.23 & 0.23 & 0.23 & 0.24 & 0.24 & 0.24 & 0.24 & 0.24 & 0.26 & 0.26 & 0.26 & 0.31 \\
\hline Bhutan & 0.18 & 0.18 & 0.18 & 0.18 & 0.18 & 0.18 & 0.18 & 0.18 & 0.18 & 0.18 & 0.18 & 0.18 & 0.39 \\
\hline India & 0.10 & 0.10 & 0.10 & 0.10 & 0.10 & 0.10 & 0.10 & 0.10 & 0.10 & 0.10 & 0.10 & 0.10 & 0.10 \\
\hline Maldives & 0.09 & 0.09 & 0.09 & 0.09 & 0.09 & 0.09 & 0.09 & 0.09 & 0.09 & 0.17 & 0.17 & 0.17 & 0.17 \\
\hline Sri Lanka & 0.57 & 0.57 & 0.57 & 0.57 & 0.60 & 0.60 & 0.60 & 0.60 & 0.60 & 0.60 & 0.60 & 0.60 & .60 \\
\hline South-Eastern Asia & 0.35 & 0.38 & 0.38 & 0.38 & 0.38 & 0.38 & 0.38 & 0.38 & 0.38 & 0.38 & 0.40 & 0.42 & 0.42 \\
\hline Cambodia & 0.64 & 0.64 & & & 0.64 & 0.64 & 0.64 & 0.64 & & 54 & 0.64 & 64 & .64 \\
\hline Indonesia & & 0.73 & 0.73 & 0.73 & 0.73 & 0.73 & 0.73 & 0.73 & 0.73 & 0.73 & 0.73 & 0.73 & 0.73 \\
\hline Lao People's democratic & & 0.39 & & 0.39 & 0.39 & 0.39 & 0.39 & 0.39 & 0.39 & 39 & 0.39 & 39 & .39 \\
\hline Malaysia & 0.37 & 0.37 & 0.37 & 0.37 & 0.37 & 0.37 & 0.37 & 0.37 & 0.37 & 0.37 & 0.37 & 0.49 & 0.49 \\
\hline Philippines & 0.29 & 0.29 & 0.29 & 0.29 & 0.29 & 0.29 & 0.29 & 0.29 & 0.29 & 0.29 & 0.29 & 0.29 & 0.29 \\
\hline Singapore & & 0.11 & 0.11 & 0.11 & 0.11 & 0.11 & 0.11 & 0.11 & 0.11 & 0.11 & 0.11 & 0.11 & 0.11 \\
\hline Thailand & 0.10 & 0.10 & 0.10 & 0.10 & 0.10 & 0.10 & 0.10 & 0.10 & 0.10 & 0.10 & 0.26 & 0.26 & 0.26 \\
\hline Western Asia & 0.38 & 0.38 & 0.40 & 0.43 & 0.43 & 0.43 & 0.47 & 0.47 & 0.47 & 0.47 & 0.47 & 0.46 & 0.48 \\
\hline Armenia & 0.66 & 0.66 & 0.66 & 0.77 & 0.77 & 0.77 & 0.77 & 0.77 & 0.77 & 0.77 & 0.77 & 0.77 & 0.77 \\
\hline Azarbaijan & 0.55 & 0.55 & 0.55 & 0.55 & 0.55 & 0.55 & 0.65 & 0.65 & 0.65 & 0.65 & 0.65 & 0.65 & 0.65 \\
\hline Georgia & 0.64 & 0.64 & 0.64 & 0.64 & 0.64 & 0.64 & 0.64 & 0.64 & 0.64 & 0.64 & 0.64 & 0.55 & 0.55 \\
\hline Iraq & 0.26 & 0.26 & 0.26 & 0.26 & 0.26 & 0.26 & 0.69 & 0.69 & 0.69 & 0.69 & 0.69 & 0.69 & 0.69 \\
\hline Israel & 0.29 & 0.29 & 0.29 & 0.29 & 0.29 & 0.29 & 0.29 & 0.29 & 0.29 & 0.29 & 0.29 & 0.29 & 0.52 \\
\hline
\end{tabular}




\begin{tabular}{|c|c|c|c|c|c|c|c|c|c|c|c|c|c|}
\hline & 1998 & 1999 & 2000 & 2001 & 2002 & 2003 & 2004 & 2005 & 2006 & 2007 & 2008 & 2009 & 2010 \\
\hline Jordan & 0.33 & 0.33 & 0.33 & 0.33 & 0.33 & 0.33 & 0.33 & 0.33 & 0.33 & 0.33 & 0.33 & 0.33 & 0.33 \\
\hline Oman & & & 0.45 & 0.45 & 0.45 & 0.45 & 0.45 & 0.45 & 0.45 & 0.45 & 0.45 & 0.45 & 0.45 \\
\hline Saudi Arabia & 0.12 & 0.12 & 0.12 & 0.12 & 0.12 & 0.12 & 0.12 & 0.12 & 0.12 & .12 & 0.12 & .12 & 12 \\
\hline Syria & 0.25 & 0.25 & 0.25 & 0.25 & 0.25 & 0.25 & 0.25 & 0.25 & 0.25 & 0.25 & 0.25 & 0.25 & 0.25 \\
\hline Turkey & 0.42 & 0.42 & 0.42 & 0.60 & 0.60 & 0.60 & 0.60 & 0.60 & 0.60 & 0.60 & 0.60 & 0.60 & 0.60 \\
\hline United Arab Emir & 0.42 & 0.42 & 0.42 & 0.42 & 0.42 & 0.42 & 0.42 & 0.42 & 0.42 & 0.42 & 0.42 & 0.42 & 0.42 \\
\hline Yemen & 0.29 & 0.29 & 0.47 & 0.47 & 0.47 & 0.47 & 0.47 & 0.47 & 0.47 & 0.47 & 0.47 & 0.47 & 0.47 \\
\hline Europe & 0.59 & 0.61 & 0.61 & 0.64 & 0.64 & 0.66 & 0.69 & 0.69 & 0.68 & 0.68 & 0.68 & 0.69 & 0.69 \\
\hline Eastern Europe & 0.57 & 0.57 & 0.58 & 0.57 & 0.56 & 0.56 & 0.59 & 0.58 & 0.58 & 0.58 & 0.58 & 0.58 & 0.58 \\
\hline Belarus & & & & 0.24 & 0.24 & 0.24 & 0.24 & 0.24 & 0.24 & 0.24 & 0.24 & 0.24 & 0.24 \\
\hline Bulgaria & 0.64 & 0.64 & 0.64 & 0.64 & 0.64 & 0.64 & 0.64 & 0.58 & 0.58 & 0.58 & 0.58 & 0.58 & 0.58 \\
\hline Czech Republic & 0.64 & 0.64 & 0.70 & 0.70 & 0.64 & 0.64 & 0.64 & 0.64 & 0.64 & 0.64 & 0.64 & 0.64 & 0.64 \\
\hline Hungary & 0.47 & 0.52 & 0.52 & 0.77 & 0.77 & 0.77 & 0.77 & 0.77 & 0.77 & 0.77 & 0.77 & 0.77 & 0.77 \\
\hline Poland & 0.32 & 0.32 & 0.32 & 0.32 & 0.32 & 0.32 & 0.32 & 0.32 & 0.32 & 0.32 & 0.32 & 0.32 & 0.37 \\
\hline Republic of Moldova & 0.68 & 0.68 & 0.68 & 0.68 & 0.68 & 0.68 & 0.68 & 0.68 & 0.68 & 0.68 & 0.68 & 0.68 & 0.68 \\
\hline Romania & 0.60 & 0.60 & 0.60 & 0.60 & 0.60 & 0.60 & 0.79 & 0.79 & 0.79 & 0.79 & 0.79 & 0.79 & 0.79 \\
\hline Russian Federation & 0.61 & 0.61 & 0.61 & 0.61 & 0.61 & 0.61 & 0.61 & 0.61 & 0.61 & 0.61 & 0.61 & 0.61 & 0.61 \\
\hline Northern Europe & 0.38 & 0.44 & 0.44 & 0.57 & 0.57 & 0.64 & 0.64 & 0.64 & 0.65 & 55 & 0.65 & 65 & .65 \\
\hline Estonia & 0.63 & 0.63 & 0.63 & 0.63 & 0.63 & 0.75 & 0.75 & 0.75 & 0.79 & 0.79 & 0.79 & 0.79 & 0.79 \\
\hline Iceland & 0.17 & 0.17 & 0.17 & 0.68 & 0.68 & 0.68 & 0.68 & 0.68 & 0.68 & 68 & .68 & 0.69 & 0.69 \\
\hline Latvia & & 0.80 & 0.80 & 0.82 & 0.83 & 0.83 & 0.83 & 0.83 & 0.83 & 0.83 & 0.83 & 0.83 & 0.83 \\
\hline Lithuania & 0.40 & 0.40 & 0.40 & 0.80 & 0.80 & 0.80 & 0.79 & 0.79 & 0.79 & 0.79 & 0.79 & 0.79 & 0.79 \\
\hline Norway & 0.11 & 0.11 & 0.11 & 0.11 & 0.11 & 0.47 & 0.47 & 0.47 & 0.47 & 0.47 & 0.47 & 0.47 & 0.47 \\
\hline Sweden & 0.77 & 0.77 & 0.77 & 0.77 & 0.77 & 0.77 & 0.77 & 0.77 & 0.77 & 0.77 & 0.77 & 0.77 & 0.77 \\
\hline United Kingdom & 0.20 & 0.20 & 0.20 & 0.20 & 0.20 & 0.20 & 0.20 & 0.20 & 0.20 & 0.20 & 0.20 & 0.23 & 0.23 \\
\hline Southern Europe & 0.61 & 0.61 & 0.61 & 0.61 & 0.61 & 0.61 & 0.72 & 0.72 & 0.70 & 0.70 & 0.70 & 0.70 & 0.70 \\
\hline Albania & 0.62 & 0.62 & 0.62 & 0.62 & 0.62 & 0.62 & 0.62 & 0.62 & 0.62 & 0.62 & 0.62 & 0.62 & 0.62 \\
\hline Bosnia and Herzegovina & 0.72 & 0.72 & 0.72 & 0.72 & 0.72 & 0.72 & 0.72 & 0.72 & 0.72 & 0.72 & 0.72 & 0.72 & 0.72 \\
\hline Croatia & 0.73 & 0.73 & 0.73 & 0.73 & 0.73 & 0.73 & 0.73 & 0.73 & 0.73 & 0.73 & 0.73 & 0.73 & 0.73 \\
\hline Macedonia & 0.36 & 0.36 & 0.36 & 0.36 & 0.36 & 0.36 & 0.83 & 0.83 & 0.74 & 0.74 & 0.74 & 0.74 & 0.74 \\
\hline Western Europe & 0.81 & 0.81 & 0.81 & 0.81 & 0.81 & 0.81 & 0.81 & 0.81 & 0.81 & 0.81 & 0.81 & 0.81 & 0.81 \\
\hline Euro Area & 0.81 & 0.81 & 0.81 & 0.81 & 0.81 & 0.81 & 0.81 & 0.81 & 0.81 & 0.81 & 0.81 & 0.81 & 0.81 \\
\hline
\end{tabular}

Table 10: Regional Independence Index (CBIW, Weighted by current US dollar GDP)

\begin{tabular}{l|l|l|l|l|l|l|l|l|l|l|l|l|l} 
& 1998 & 1999 & 2000 & 2001 & 2002 & 2003 & 2004 & 2005 & 2006 & 2007 & 2008 & 2009 & 2010 \\
\hline Africa & 0.27 & 0.27 & 0.31 & 0.32 & 0.33 & 0.31 & 0.31 & 0.31 & 0.33 & 0.34 & 0.36 & 0.35 & 0.34 \\
\hline Eastern Africa & 0.43 & 0.43 & 0.46 & 0.46 & 0.46 & 0.46 & 0.46 & 0.46 & 0.49 & 0.49 & 0.49 & 0.49 & 0.49 \\
\hline Northern Africa & 0.00 & 0.00 & 0.46 & 0.46 & 0.46 & 0.46 & 0.46 & 0.46 & 0.46 & 0.46 & 0.46 & 0.46 & 0.46 \\
\hline Middle Africa & 0.52 & 0.52 & 0.52 & 0.52 & 0.52 & 0.52 & 0.52 & 0.52 & 0.52 & 0.52 & 0.52 & 0.52 & 0.52 \\
\hline Southern Africa & 0.17 & 0.17 & 0.17 & 0.17 & 0.17 & 0.17 & 0.17 & 0.17 & 0.17 & 0.17 & 0.17 & 0.17 & 0.17 \\
\hline Western Africa & 0.50 & 0.49 & 0.49 & 0.49 & 0.49 & 0.49 & 0.49 & 0.49 & 0.49 & 0.51 & 0.51 & 0.51 & 0.51 \\
\hline Americas & 0.23 & 0.23 & 0.23 & 0.23 & 0.23 & 0.23 & 0.23 & 0.23 & 0.24 & 0.24 & 0.24 & 0.23 & 0.24 \\
\hline Latin A. \& Carib. & 0.17 & 0.17 & 0.23 & 0.23 & 0.23 & 0.23 & 0.23 & 0.24 & 0.24 & 0.24 & 0.24 & 0.24 & 0.23 \\
\hline Central America & 0.63 & 0.63 & 0.63 & 0.63 & 0.63 & 0.63 & 0.63 & 0.63 & 0.63 & 0.63 & 0.63 & 0.63 & 0.63 \\
\hline South America & 0.50 & 0.49 & 0.48 & 0.57 & 0.53 & 0.53 & 0.54 & 0.54 & 0.54 & 0.54 & 0.54 & 0.55 & 0.55 \\
\hline Northern America & 0.20 & 0.20 & 0.20 & 0.20 & 0.20 & 0.20 & 0.20 & 0.20 & 0.20 & 0.20 & 0.20 & 0.20 & 0.20 \\
\hline Oceania & 0.22 & 0.22 & 0.22 & 0.22 & 0.19 & 0.19 & 0.19 & 0.19 & 0.19 & 0.19 & 0.19 & 0.19 & 0.19 \\
\hline Australia and New Zealand & 0.22 & 0.22 & 0.22 & 0.22 & 0.19 & 0.19 & 0.19 & 0.19 & 0.19 & 0.19 & 0.18 & 0.18 & 0.18 \\
\hline Melanesia & 0.33 & 0.33 & 0.47 & 0.46 & 0.46 & 0.46 & 0.46 & 0.46 & 0.47 & 0.47 & 0.47 & 0.48 & 0.48 \\
\hline
\end{tabular}




\begin{tabular}{l|l|l|l|l|l|l|l|l|l|l|l|l|l} 
& 1998 & 1999 & 2000 & 2001 & 2002 & 2003 & 2004 & 2005 & 2006 & 2007 & 2008 & 2009 & 2010 \\
\hline Polynesia & 0.20 & 0.20 & 0.20 & 0.20 & 0.20 & 0.20 & 0.20 & 0.20 & 0.20 & 0.20 & 0.20 & 0.20 & 0.20 \\
\hline Asia & 0.33 & 0.35 & 0.35 & 0.35 & 0.36 & 0.36 & 0.36 & 0.36 & 0.37 & 0.37 & 0.38 & 0.38 & 0.38 \\
\hline Central Asia & 0.83 & 0.83 & 0.83 & 0.83 & 0.83 & 0.83 & 0.83 & 0.83 & 0.83 & 0.83 & 0.83 & 0.83 & 0.83 \\
\hline Eastern Asia & 0.37 & 0.37 & 0.37 & 0.37 & 0.37 & 0.37 & 0.38 & 0.38 & 0.38 & 0.39 & 0.40 & 0.40 & 0.40 \\
\hline Southern Asia & 0.12 & 0.12 & 0.12 & 0.12 & 0.12 & 0.12 & 0.12 & 0.12 & 0.12 & 0.12 & 0.12 & 0.12 & 0.12 \\
\hline South-Eastern Asia & 0.14 & 0.35 & 0.36 & 0.37 & 0.38 & 0.40 & 0.39 & 0.39 & 0.40 & 0.40 & 0.44 & 0.46 & 0.48 \\
\hline Western Asia & 0.32 & 0.32 & 0.31 & 0.36 & 0.37 & 0.39 & 0.40 & 0.41 & 0.41 & 0.42 & 0.42 & 0.42 & 0.45 \\
\hline Europe & 0.71 & 0.71 & 0.70 & 0.70 & 0.70 & 0.71 & 0.71 & 0.71 & 0.71 & 0.71 & 0.71 & 0.72 & 0.72 \\
\hline Eastern Europe & 0.51 & 0.50 & 0.52 & 0.54 & 0.54 & 0.55 & 0.57 & 0.57 & 0.57 & 0.57 & 0.57 & 0.57 & 0.58 \\
\hline Northern Europe & 0.27 & 0.27 & 0.27 & 0.27 & 0.27 & 0.31 & 0.31 & 0.31 & 0.31 & 0.31 & 0.33 & 0.35 & 0.35 \\
\hline Southern Europe & 0.68 & 0.68 & 0.68 & 0.68 & 0.68 & 0.68 & 0.72 & 0.72 & 0.71 & 0.71 & 0.71 & 0.71 & 0.71 \\
\hline Western Europe & 0.81 & 0.81 & 0.81 & 0.81 & 0.81 & 0.81 & 0.81 & 0.81 & 0.81 & 0.81 & 0.81 & 0.81 & 0.81 \\
\hline
\end{tabular}

Figure 4: Comparison of Independence Index in 1998 and 2010 (CBIW)

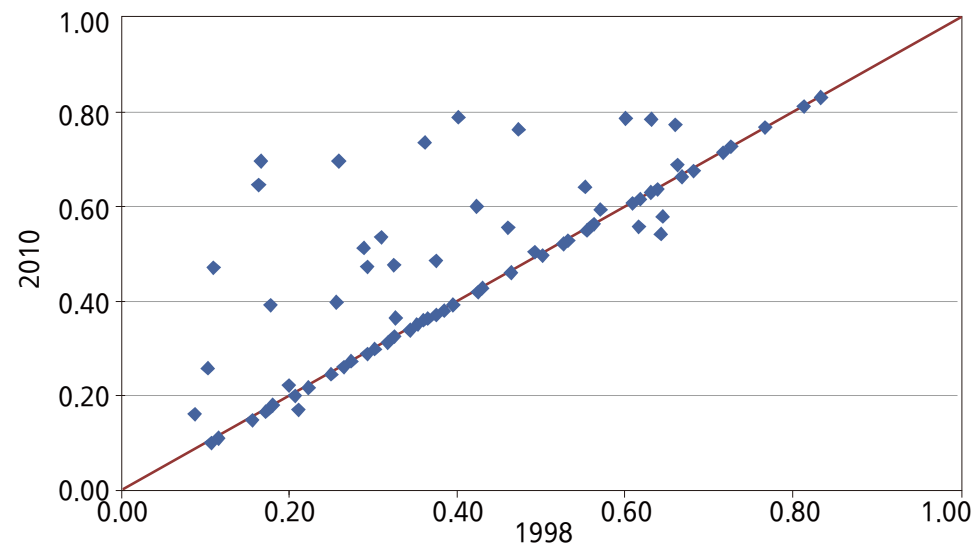

Figure 4 compares central bank independence in 1998 and 2010 according to CBIW, our extended weighted index. The overall trend is in the direction of greater independence. Six central banks, those of Iceland, Venezuela, Iraq, Lithuania, Macedonia and Norway, show especially dramatic increases over the period. Argentina, Australia, Bulgaria and Georgia are exceptions to the trend. The law governing the Reserve Bank of Australia was changed in 2002; law changed in 2002: previously the governor and board members were appointed by the governor general; in 2002 appointment power was given to the treasurer, who is a minister (member of the executive branch), producing a lower score. Moreover, whereas board members had been appointed for exactly five years, after the amendment the term was specified as not exceeding five years at the discretion of the appointer.

We turn now to the country correlates of independence. The basic specification 
used to analyze the correlates of central bank independence is similar to that used above to analyze the correlates of transparency, since the two variables are broadly thought to respond to similar factors. The respective regressions are best understood as reduced-form estimates of the determinants of the respective variables. In the case of independence, we again include past inflation, openness, financial depth, GDP per capita and various measures of the strength of institutions as explanatory variables. In addition we consider the national origin of the legal system (which has been shown elsewhere to be important for the structure of financial institutions) and the value of IMF lending to the country relative to its GDP (during the period covered by the dependent variable) as a measure of Fund influence over arrangements.

\section{Table 11: Determinants of Central Bank Independence (CBIW), 1998-2010 Averages ${ }^{1 / 2) 3)}$}

\begin{tabular}{|c|c|c|c|c|c|c|c|c|c|c|}
\hline & I & $\|$ & III & IV & V & VI & VII & VIII & IX & $x$ \\
\hline Constant & \begin{tabular}{|c|}
$0.55^{*}$ \\
$(3.04)$
\end{tabular} & $\begin{array}{c}0.33 \\
(1.68)\end{array}$ & $\begin{array}{l}0.71^{*} \\
(3.88)\end{array}$ & $\begin{array}{l}0.71^{*} \\
(3.61)\end{array}$ & $\begin{array}{l}0.55^{*} \\
(2.29)\end{array}$ & $\begin{array}{l}0.64^{*} \\
(3.18)\end{array}$ & $\begin{array}{l}0.66^{*} \\
(2.56)\end{array}$ & $\begin{array}{l}0.78^{*} \\
(3.95)\end{array}$ & $\begin{array}{l}0.85^{*} \\
(3.61)\end{array}$ & $\begin{array}{l}0.59^{*} \\
(2.32)\end{array}$ \\
\hline Past Inflation & $\begin{array}{c}0.06 \\
(0.31)\end{array}$ & $\begin{array}{c}0.03 \\
(0.15)\end{array}$ & $\begin{array}{l}-0.20 \\
(-1.30)\end{array}$ & $\begin{array}{c}-0.19 \\
(-1.23)\end{array}$ & $\begin{array}{l}-0.25 \\
(-1.57)\end{array}$ & $\begin{array}{l}-0.22 \\
(-1.42)\end{array}$ & $\begin{array}{l}-0.21 \\
(-1.32)\end{array}$ & $\begin{array}{c}-0.17 \\
(-1.14)\end{array}$ & $\begin{array}{l}-0.15 \\
(-0.96)\end{array}$ & $\begin{array}{l}-0.22 \\
(-0.44)\end{array}$ \\
\hline Openness & $\mid \begin{array}{l}-0.01 \\
(-0.20)\end{array}$ & $\begin{array}{l}-0.01 \\
(-0.14)\end{array}$ & $\begin{array}{c}0.01 \\
(0.38)\end{array}$ & $\begin{array}{c}0.05 \\
(1.20)\end{array}$ & $\begin{array}{c}0.02 \\
(0.45)\end{array}$ & $\begin{array}{c}0.02 \\
(0.59)\end{array}$ & $\begin{array}{c}0.01 \\
(0.40)\end{array}$ & $\begin{array}{c}0.02 \\
(0.54)\end{array}$ & $\begin{array}{c}0.01 \\
(0.32)\end{array}$ & $\begin{array}{c}0.01 \\
(0.42)\end{array}$ \\
\hline Financial Depth & $\begin{array}{l}-0.15^{*} \\
(-2.13)\end{array}$ & $\begin{array}{l}-0.17^{*} \\
(-2.51)\end{array}$ & $\begin{array}{l}-0.14^{*} \\
(-2.55)\end{array}$ & $\begin{array}{l}-0.14^{*} \\
(-2.36)\end{array}$ & $\begin{array}{l}-0.13^{*} \\
(-2.32)\end{array}$ & $\begin{array}{l}-0.14^{*} \\
(-2.52)\end{array}$ & $\begin{array}{l}-0.14^{*} \\
(-2.42)\end{array}$ & $\begin{array}{l}-0.14^{*} \\
(-2.56)\end{array}$ & $\begin{array}{l}-0.15^{*} \\
(-2.58)\end{array}$ & $\begin{array}{l}-0.14^{*} \\
(-2.44)\end{array}$ \\
\hline GDP per Capita & $\begin{array}{c}-0.00 \\
(-0.10)\end{array}$ & $\begin{array}{c}0.02 \\
(0.89)\end{array}$ & $\begin{array}{l}-0.01 \\
(-0.45)\end{array}$ & $\begin{array}{l}-0.02 \\
(-0.90)\end{array}$ & $\begin{array}{c}0.01 \\
(0.39)\end{array}$ & $\begin{array}{l}-0.00 \\
(-0.05)\end{array}$ & $\begin{array}{l}-0.00 \\
(-0.09)\end{array}$ & $\begin{array}{l}-0.02 \\
(-0.86)\end{array}$ & $\begin{array}{c}-0.02 \\
(-0.97)\end{array} \mid$ & $\begin{array}{c}0.01 \\
(0.19)\end{array}$ \\
\hline IMF Lending & & $\begin{array}{l}3.04^{*} \\
(2.56)\end{array}$ & $\begin{array}{l}2.62^{*} \\
(2.67)\end{array}$ & $\begin{array}{c}2.22 \\
(2.14)\end{array}$ & $\begin{array}{l}2.76^{*} \\
(2.79)\end{array}$ & $\begin{array}{l}2.72^{*} \\
(2.75)\end{array}$ & $\begin{array}{l}2.65^{*} \\
(2.67)\end{array}$ & $\begin{array}{l}2.48^{*} \\
(2.51)\end{array}$ & $\begin{array}{l}2.45^{*} \\
(2.46)\end{array}$ & $\begin{array}{l}2.72^{*} \\
(2.74)\end{array}$ \\
\hline Legal Origin: UK & & & $\begin{array}{l}-0.26^{*} \\
(-5.55)\end{array}$ & $\begin{array}{l}-0.23^{*} \\
(-4.47)\end{array}$ & $\begin{array}{l}-0.26^{*} \\
(-5.49)\end{array}$ & $\begin{array}{l}-0.26^{*} \\
(-5.59)\end{array}$ & $\begin{array}{l}-0.26^{*} \\
(-5.49)\end{array}$ & $\begin{array}{l}-0.26^{*} \\
(-5.50)\end{array}$ & $\left|\begin{array}{c}-0.26^{*} \\
(-5.54)\end{array}\right|$ & $\begin{array}{l}-0.25^{*} \\
(-5.39)\end{array}$ \\
\hline Legal Origin: Fr & & & $\begin{array}{l}-0.07 \\
(-1.38)\end{array}$ & $\begin{array}{c}-0.03 \\
(-0.57)\end{array}$ & $\begin{array}{l}-0.08 \\
(-1.62)\end{array}$ & $\begin{array}{l}-0.08 \\
(-1.54)\end{array}$ & $\begin{array}{l}-0.07 \\
(-1.40)\end{array}$ & $\begin{array}{l}-0.05 \\
(-0.98)\end{array}$ & $\begin{array}{l}-0.06 \\
(-1.16)\end{array}$ & $\begin{array}{l}-0.07 \\
(-1.49)\end{array}$ \\
\hline Democracy & & & & $\begin{array}{c}0.01 \\
(1.43)\end{array}$ & & & & & & \\
\hline Rule of Law & & & & & $\begin{array}{c}-0.04 \\
(-1.06)\end{array}$ & & & & & \\
\hline Political Stability & & & & & & $\begin{array}{l}-0.02 \\
(-0.80)\end{array}$ & & & & \\
\hline Government Efficiency & & & & & & & $\begin{array}{c}-0.01 \\
(-0.30)\end{array}$ & & & \\
\hline
\end{tabular}




\begin{tabular}{|c|c|c|c|c|c|c|c|c|c|c|}
\hline & 1 & $\|$ & III & IV & V & VI & VII & VIII & IX & $x$ \\
\hline Accountability & & & & & & & & $\begin{array}{c}0.03 \\
(0.97)\end{array}$ & & \\
\hline Regulatory Quality & & & & & & & & & $\begin{array}{c}0.03 \\
(0.94)\end{array}$ & \\
\hline Correlation & & & & & & & & & & $\begin{array}{l}-0.02 \\
(-0.69)\end{array}$ \\
\hline R-Squared & 0.08 & 0.19 & 0.47 & 0.44 & 0.48 & 0.47 & 0.47 & 0.48 & 0.47 & 0.47 \\
\hline
\end{tabular}

Notes : 1) * denotes significance at $5 \%$.

2) t-statistics in parentheses.

3) The definition of independent variables are as follows: Past inflation is the logarithmic value of 1 plus the lagged inflation rate; openness is the share of the sum of exports and imports to GDP; financial depth is the ratio of M2 to GDP; GDP per capita is the logarithm of constant GDP per capita; rule of law, political stability, voice and accountability and government efficiency are from Governance Indicators Database; and democracy, autocracy and Polity are taken from Polity Database.

Table 12: Determinants of Central Bank Independence (CBIW), Panel Fixed Effects ${ }^{1 / 2) 3 \text { ) }}$

\begin{tabular}{|c|c|c|c|c|c|c|c|c|c|c|}
\hline & I & \| & III & IV & V & VI & VII & VIII & IX & X \\
\hline Constant & $\begin{array}{c}0.45 \\
(0.01)\end{array}$ & $\begin{array}{c}0.35 \\
(0.01)\end{array}$ & $\begin{array}{c}0.68 \\
(0.02)\end{array}$ & $\begin{array}{c}0.70 \\
(0.02)\end{array}$ & $\begin{array}{c}0.31 \\
(0.01)\end{array}$ & $\begin{array}{c}0.52 \\
(0.02)\end{array}$ & $\begin{array}{c}0.43 \\
(0.01)\end{array}$ & $\begin{array}{c}0.54 \\
(0.02)\end{array}$ & $\begin{array}{c}0.55 \\
(0.02)\end{array}$ & $\begin{array}{c}0.37 \\
(0.01)\end{array}$ \\
\hline ast Ir & $\begin{array}{c}0.04 \\
(1.13)\end{array}$ & $\begin{array}{c}0.01 \\
(0.29)\end{array}$ & $\begin{array}{l}-0.03 \\
(-1.12)\end{array}$ & $\begin{array}{l}-0.04 \\
(-1.52)\end{array}$ & $\begin{array}{l}-0.05 \\
(-1.78)\end{array}$ & $\begin{array}{l}-0.06 \\
(-1.80)\end{array}$ & $\begin{array}{l}-0.04 \\
(-1.38)\end{array}$ & $\begin{array}{l}-0.04 \\
(-1.28)\end{array}$ & $\begin{array}{l}-0.05 \\
(-1.53)\end{array}$ & $\begin{array}{l}-0.04 \\
(-1.32)\end{array}$ \\
\hline Openness & $\begin{array}{c}0.00 \\
(1.88)\end{array}$ & $\begin{array}{l}0.00^{*} \\
(2.10)\end{array}$ & $\begin{array}{c}0.00^{*} \\
(2.43)\end{array}$ & $\begin{array}{l}0.00^{*} \\
(2.25)\end{array}$ & $\begin{array}{l}0.00^{*} \\
(2.58)\end{array}$ & \begin{tabular}{|c|}
$0.00^{*}$ \\
$(2.75)$
\end{tabular} & $\mid \begin{array}{c}0.00 \\
(1.93)\end{array}$ & $\begin{array}{l}0.00^{*} \\
(2.38)\end{array}$ & $\begin{array}{l}0.00^{*} \\
(2.06)\end{array}$ & $\begin{array}{l}0.00^{*} \\
(2.16)\end{array}$ \\
\hline Financial Depth & $\begin{array}{c}0.00 \\
(0.81)\end{array}$ & $\begin{array}{l}-0.00 * \\
(-1.82)\end{array}$ & $\begin{array}{c}0.00 \\
(0.49)\end{array}$ & $\begin{array}{l}-0.00 \\
(-1.51)\end{array}$ & $\begin{array}{c}0.00 \\
(0.29)\end{array}$ & $\begin{array}{c}0.00 \\
(0.03)\end{array}$ & $\begin{array}{c}0.00 \\
(0.38)\end{array}$ & $\begin{array}{c}0.00 \\
(0.40)\end{array}$ & $\begin{array}{c}0.00 \\
(0.21)\end{array}$ & $\begin{array}{c}0.00 \\
(0.34)\end{array}$ \\
\hline GDP per Capita & $\begin{array}{l}-0.00 \\
(-0.10)\end{array}$ & $\begin{array}{c}0.01 \\
(1.46)\end{array}$ & $\left|\begin{array}{l}-0.02^{*} \\
(-2.19)\end{array}\right|$ & $\left|\begin{array}{l}-0.02^{*} \\
(-2.10)\end{array}\right|$ & $\begin{array}{l}0.02^{* *} \\
(2.20)\end{array}$ & $\begin{array}{l}-0.00 \\
(-0.06)\end{array}$ & $\left.\mid \begin{array}{c}0.01 \\
(1.02)\end{array}\right)$ & $\begin{array}{l}-0.00 \\
(-0.36)\end{array}$ & $\left|\begin{array}{l}-0.00 \\
(-0.34)\end{array}\right|$ & $\begin{array}{c}0.02 \\
(1.50)\end{array}$ \\
\hline IMF Lenc & & $\begin{array}{l}0.99^{*} \\
(4.30)\end{array}$ & $\begin{array}{l}0.78^{*} \\
(3.60)\end{array}$ & $\begin{array}{l}0.55^{*} \\
(2.68)\end{array}$ & $\begin{array}{l}0.95^{*} \\
(4.55)\end{array}$ & $\begin{array}{l}0.92^{*} \\
(4.28)\end{array}$ & $\begin{array}{l}0.88^{*} \\
(4.13)\end{array}$ & $\begin{array}{l}0.90^{*} \\
(4.08)\end{array}$ & $\begin{array}{l}0.87^{*} \\
(3.98)\end{array}$ & $\begin{array}{l}0.93^{*} \\
(4.40)\end{array}$ \\
\hline Legal Origin: UK & & & $\left|\begin{array}{l}-0.19^{*} \\
(-8.25)\end{array}\right|$ & $\left|\begin{array}{l}-0.13^{*} \\
(-5.52)\end{array}\right|$ & $\begin{array}{l}-0.17^{*} \\
(-7.69)\end{array}$ & $\begin{array}{l}-0.19^{*} \\
(-8.53)\end{array}$ & $\left|\begin{array}{l}-0.17^{*} \\
(-7.57)\end{array}\right|$ & $\begin{array}{l}-0.18^{*} \\
(-7.65)\end{array}$ & $\left|\begin{array}{l}-0.18^{*} \\
(-8.08)\end{array}\right|$ & $\begin{array}{l}-0.16^{*} \\
(-7.18)\end{array}$ \\
\hline Lega & & & $\begin{array}{l}-0.02 \\
(-0.92)\end{array}$ & $\begin{array}{l}-0.01 \\
(-0.51)\end{array}$ & $\begin{array}{l}-0.03 \\
(-1.58)\end{array}$ & -0.04 & -0.03 & -0.03 & -0.02 & $\begin{array}{c}-0.02 \\
(-1.02)\end{array}$ \\
\hline Demo & & & & $\left|\begin{array}{l}-0.00 * \\
(-3.51)\end{array}\right|$ & & & & & & \\
\hline Rule of Law & & & & & $\begin{array}{l}-0.07^{*} \\
(-7.75)\end{array}$ & & & & & \\
\hline
\end{tabular}




\begin{tabular}{|c|c|c|c|c|c|c|c|c|c|c|}
\hline & 1 & $\|$ & III & IV & V & $\mathrm{VI}$ & VII & VIII & IX & $x$ \\
\hline Political Stability & & & & & & $\begin{array}{l}-0.04^{*} \\
(-4.77)\end{array}$ & & & & \\
\hline Government Efficiency & & & & & & & $\begin{array}{l}-0.05^{*} \\
(-5.21)\end{array}$ & & & \\
\hline Accountability & & & & & & & & $\begin{array}{l}-0.03^{*} \\
(-2.67)\end{array}$ & & \\
\hline Regulatory Quality & & & & & & & & & $\begin{array}{l}-0.03^{*} \\
(-2.86)\end{array}$ & \\
\hline Correlation & & & & & & & & & & $\begin{array}{l}-0.06^{*} \\
(-6.32)\end{array}$ \\
\hline Haussman Test & $9.97^{*}$ & 7.59 & 10.34 & 13.13 & 10.40 & 10.43 & 10.29 & 13.95 & $16.07^{*}$ & 9.93 \\
\hline R-Squared & 0.96 & 0.97 & 0.97 & 0.98 & 0.97 & 0.97 & 0.97 & 0.97 & 0.97 & 0.97 \\
\hline
\end{tabular}

Notes : 1) * denotes significance at $5 \%$.

2) t-statistics in parentheses.

3) The definition of independent variables are as follows: Past inflation is the logarithmic value of 1 plus the lagged inflation rate; openness is the share of the sum of exports and imports to GDP; financial depth is the ratio of M2 to GDP; GDP per capita is the logarithm of constant GDP per capita; rule of law, political stability, voice and accountability and government efficiency are from Governance Indicators Database; and democracy, autocracy and Polity are taken from Polity Database.

Table 11 reports a cross-section regression for the determinants of independence, with all variables averaged over the 1998-2010 period. It suggests that countries under the financial tutelage of the IMF and with less developed financial markets have more independent central banks. Table 12 reports the same regressions using annual data and country fixed effects. These results suggest that central bank independence has tended to increase over time in more open economies and in countries that have participated in IMF programs, while decreasing in countries with a British legal tradition (interestingly insofar as the Bank of England itself is a prominent example of a central bank that became more independent over the period). There is no evidence that countries with more robust institutions strengthened the independence of their central banks, perhaps because the level of central bank independence was already high. If anything the opposite is true. 
Table 13: Effect of Central Bank Independence on Inflation Variability ${ }^{1 / 2) 3)}$ (GMM, full sample)

\begin{tabular}{l|c|c|c|c|c|c|c}
\hline Constant & I & II & III & IV & V & VI \\
& $16.78^{*}$ & $25.33^{*}$ & $11.85^{*}$ & $1.48^{*}$ & $14.44^{*}$ & 3.85 \\
& $(1.99)$ & $(3.08)$ & $(2.59)$ & $(2.39)$ & $(2.92)$ & $(1.55)$ \\
\hline Independence Index & $-3.08^{*}$ & $-1.48^{*}$ & $-1.03^{*}$ & -0.41 & $-1.41^{*}$ & $-0.46^{*}$ \\
& $(-1.71)$ & $(-2.29)$ & $(-1.75)$ & $(-1.76)$ & $(-2.31)$ & $(-1.87)$ \\
\hline Openness & & $-0.19^{*}$ & & & -0.01 & -0.01 \\
& & $(-2.92)$ & & & $(-1.09)$ & $(-1.31)$ \\
\hline Financial Depth & & & $-0.09^{*}$ & & $-0.10^{*}$ & -0.02 \\
& & & $(-2.59)$ & & $(-2.84)$ & $(-0.88)$ \\
\hline Past Inflation & & & & $34.82^{*}$ & & $25.56^{*}$ \\
& & & & $(4.95)$ & & $(2.57)$ \\
\hline Durbin-Watson statistics & 0.29 & 0.27 & 0.54 & 0.97 & 0.50 & 0.90 \\
\hline J-statistics & 0.00 & 0.00 & 4.65 & 1.70 & 5.35 & 1.63 \\
\hline Number of observations & 935 & 935 & 935 & 935 & 935 & 935 \\
\hline Sum of Sq. Res. & 69167 & 140687 & 37089 & 12952 & 41419 & 13417 \\
\hline
\end{tabular}

Notes : 1) * denotes significance at $10 \%$.

2) t-statistics in parentheses.

3) Dependent variable is inflation variability, which is the standard deviation of the inflation rate for 12 months. Central bank independence index is CBIW.

The definitions of independent variables are as follows: Past inflation is the logarithmic value of 1 plus the lagged inflation rate; openness is the share of the sum of exports and imports to GDP; financial depth is the ratio of M2 to GDP. The instrumental variables are rule of law, political stability, accountability, government efficiency and regulatory quality which are taken from Governance Indicators Database and democracy, taken from Polity database.

Table 14: Effect of Central Bank Independence on Inflation ${ }^{1223)}$

(GMM, full sample)

\begin{tabular}{l|c|c|c|c|c|c}
\hline & I & II & III & IV & V & VI \\
\hline Constant & $-25.91^{*}$ & $11.14^{*}$ & $17.24^{*}$ & $1.58^{*}$ & $25.10^{*}$ & 3.94 \\
& $(-9.94)$ & $(4.52)$ & $(2.78)$ & $(1.14)$ & $(6.59)$ & $(0.49)$ \\
\hline Independence Index & $-7.23^{*}$ & $-1.65^{*}$ & -0.34 & -0.38 & $-1.14^{*}$ & -0.31 \\
& $(11.71)$ & $(-3.80)$ & $(-1.16)$ & $(-0.90)$ & $(-3.04)$ & $(-1.25)$ \\
\hline Openness & & $-0.61^{*}$ & & & $-0.07^{*}$ & -0.02 \\
& & $(-4.16)$ & & & $(-3.02)$ & $(-0.92)$ \\
\hline Financial Depth & & & $-0.00^{*}$ & & $-0.00^{*}$ & -0.21 \\
& & & $(-6.18)$ & & $(-9.28)$ & $(-0.03)$ \\
\hline Past Inflation & & & & $0.91^{*}$ & & $0.81^{*}$ \\
& & & & $(10.12)$ & & $(2.03)$ \\
\hline
\end{tabular}




\begin{tabular}{l|c|c|c|c|c|c|c|}
\hline & I & II & III & IV & V & VI \\
\hline Durbin-Watson statistics & 0.17 & 0.15 & 0.35 & 1.66 & 0.34 & 0.36 \\
\hline J-statistics & 0.00 & 0.00 & 0.81 & 1.70 & 1.78 & 0.74 \\
\hline Number of observations & 1088 & 1088 & 1088 & 1088 & 1088 & 1088 \\
\hline Sum of Sq. Res. & 315650 & 1948604 & 127206 & 85708 & 148069 & 73756 \\
\hline
\end{tabular}

Notes : 1) * denotes significance at $10 \%$

2) t-statistics in parentheses, based on White cross section standard errors (degrees of freedom corrected).

3) Dependent variable is inflation variability, which is the standard deviation of the inflation rate for the 12 months of the calendar year. Central bank independence index is CBIW. The definitions of independent variables are as follows: Past inflation is the logarithmic value of 1 plus the lagged inflation rate; openness is the share of the sum of exports and imports to GDP; financial depth is the ratio of M2 to GDP. The instrumental variables are rule of law, political stability, accountability, government efficiency and regulatory quality which are taken from Governance Indicators Database and democracy, taken from Polity database.

Tables13 and 14 repeat our previous regressions for inflation and inflation variability. Table 13 shows that inflation variability is less in countries where the central bank is more independent, while Table 14 replicates the results of previous studies on smaller country samples that there is some, albeit statistically inconsistent negative association between central bank independence and the average level of inflation.

Table 15: Effect of Both Central Bank Transparency and Independence on Inflation Variability (GMM, full sample) ${ }^{12 / 3)}$

\begin{tabular}{l|c|c|c|c|c|c|} 
& $\mathrm{I}$ & $\mathrm{II}$ & $\mathrm{III}$ & $\mathrm{IV}$ & $\mathrm{V}$ & $\mathrm{VI}$ \\
\hline Constant & $7.40^{*}$ & $13.77^{*}$ & $9.91^{*}$ & 1.59 & $11.82^{*}$ & $4.19^{*}$ \\
& $(1.93)$ & $(2.28)$ & $(2.76)$ & $(1.24)$ & $(2.88)$ & $(1.69)$ \\
\hline Independence Index & -0.26 & -0.84 & $-0.69^{*}$ & -0.06 & -0.67 & -0.48 \\
& $(-0.50)$ & $(-1.28)$ & $(-1.67)$ & $(-0.28)$ & $(-1.63)$ & $(-1.57)$ \\
\hline Transparency Index & $-0.75^{*}$ & $-0.61^{*}$ & $-0.13^{*}$ & -0.17 & $-0.44^{*}$ & -0.01 \\
& $(-2.72)$ & $(-2.57)$ & $(-3.16)$ & $(-1.15)$ & $(-2.61)$ & $(-0.09)$ \\
\hline Openness & & $-0.05^{*}$ & & & $-0.03^{*}$ & -0.01 \\
& & $(-2.00)$ & & & $(-2.06)$ & $(-0.71)$ \\
\hline Financial Depth & & & $-0.07^{*}$ & & -0.02 & -0.02 \\
& & & $(-2.49)$ & & $(-0.72)$ & $(-1.07)$ \\
\hline Past Inflation & & & & $23.91^{*}$ & & $24.65^{*}$ \\
& & & & $(4.79)$ & & $(1.92)$ \\
\hline Joint Signif. F-test & $10.30^{*}$ & $14.92^{*}$ & $5.06^{*}$ & 0.67 & $3.53^{*}$ & 1.91 \\
\hline Durbin-Watson statistics & 0.65 & 0.53 & 0.61 & 1.00 & 0.60 & 0.89 \\
\hline J-statistics & 0.00 & 0.00 & 4.96 & 0.76 & 0.70 & 1.60 \\
\hline
\end{tabular}




\begin{tabular}{l|c|c|c|c|c|c|}
\hline & I & II & III & IV & V & VI \\
\hline Number of observations & 935 & 935 & 935 & 935 & 935 & 935 \\
\hline Sum of Sq. Res. & 30486 & 41409 & 32563 & 12106 & 35015 & 13697 \\
\hline
\end{tabular}

Notes: 1) * denotes significance at $10 \%$.

2) t-statistics in parentheses, based on White cross section standard errors (degrees of freedom corrected).

3) Dependent variable is inflation variability, which is the standard deviation of the inflation rate for the 12 months of the calendar year. Central bank independence index is CBIW. The definitions of independent variables are as follows: Past inflation is the logarithmic value of 1 plus the lagged inflation rate; openness is the share of the sum of exports and imports to GDP; financial depth is the ratio of M2 to GDP. The instrumental variables are rule of law, political stability, accountability, government efficiency and regulatory quality which are taken from Governance Indicators Database and democracy, taken from Polity database.

Table 16: Effect of Both Central Bank Transparency and Independence on Inflation (GMM, full sample) ${ }^{1 / 2 / 3)}$

\begin{tabular}{l|c|c|c|c|c|c} 
& $\mathrm{I}$ & $\mathrm{II}$ & $\mathrm{III}$ & $\mathrm{IV}$ & $\mathrm{V}$ & $\mathrm{VI}$ \\
\hline Constant & $12.88^{*}$ & $20.54^{*}$ & $43.50^{*}$ & 1.46 & -2.73 & -0.43 \\
& $(4.44)$ & $(4.36)$ & $(3.26)$ & $(0.93)$ & $(-0.13)$ & $(-0.07)$ \\
\hline Independence Index & 0.46 & 0.28 & $-4.55^{*}$ & -0.23 & 5.20 & 1.18 \\
& $(0.99)$ & $(0.47)$ & $(-2.04)$ & $(-0.50)$ & $(1.13)$ & $(1.04)$ \\
\hline Transparency Index & $-1.67^{*}$ & $-1.19^{*}$ & 0.77 & -0.04 & -3.20 & -0.67 \\
& $(-6.65)$ & $(-7.05)$ & $(1.02)$ & $(-0.19)$ & $(-1.46)$ & $(-1.19)$ \\
\hline Openness & & $-0.11^{*}$ & & & $-0.22^{*}$ & -0.07 \\
& & $(-4.50)$ & & & $(-2.23)$ & $(-0.40)$ \\
\hline Financial Depth & & & $-0.40^{*}$ & & 0.00 & 0.00 \\
& & & $(-2.90)$ & & $(1.01)$ & $(1.07)$ \\
\hline Past Inflation & & & & $0.87^{*}$ & & $0.76^{*}$ \\
& & & & $(5.10)$ & & $(4.15)$ \\
\hline Joint Signif. F-test & $39.31^{*}$ & $26.48^{*}$ & $5.13^{*}$ & 0.35 & $4.58^{*}$ & 0.74 \\
\hline Durbin-Watson statistics & 0.37 & 0.37 & 0.21 & 1.69 & 0.21 & 1.23 \\
\hline J-statistics & 0.00 & 0.00 & 0.00 & 0.02 & 0.00 & 0.10 \\
\hline Number of observations & 1075 & 1075 & 1075 & 1075 & 1075 & 991 \\
\hline Sum of Sq. Res. & 118490 & 145798 & 287096 & 78765 & 480122 & 86852 \\
\hline
\end{tabular}

Notes : 1) * denotes significance at $10 \%$

2) t-statistics in parentheses, based on White cross section standard errors (degrees of freedom corrected).

3) Dependent variable is inflation variability, which is the standard deviation of the inflation rate for the 12 months of the calendar year. Central bank independence index is CBIW. The definitions of independent variables are as follows: Past inflation is the logarithmic value of 1 plus the lagged inflation rate; openness is the share of the sum of exports and imports to GDP; financial depth is the ratio of $M 2$ to GDP. The instrumental variables are rule of law, political stability, accountability, government efficiency and regulatory quality which are taken from Governance Indicators Database and democracy, taken from Polity database. 
Tables 15 and 16 include both central bank independence and transparency. Transparency is significant more often than independence (as above). However, the two variables are jointly significant in most specifications (as indicated by the F-test for the joint statistical significance of their respective coefficients toward the foot of each column). Evidently, determining which measure matters more for inflation variability is asking too much of the data - not surprisingly, given the extent to which the two attributes are correlated and respond to the same determinants.

\section{Conclusion}

In this paper we have reported updated measures of transparency and independence for upwards of 100 central banks. Our indices for the period 1998-2010 show that there has been steady movement in the direction of greater transparency and independence over time, encompassing advanced countries, emerging markets and developing economies alike. While there are exceptions, there is little indication of these broad trends toward greater central bank independence and transparency being rethought and reversed as a result of the global financial crisis.

Our analysis of these two dimensions of monetary policy arrangements confirms the impression that central bank independence and transparency go together that they respond to the same or, at least, related imperatives. Independence gives central banks more freedom of choice in their tactics, while transparency is a way for them to communicate the intent of those tactics to the markets and thereby enhance the effectiveness of their policies. Independence gives central banks insulation from political pressures, while transparency about their intentions and actions is a way of holding them accountable for their decisions in the court of public opinion. We find that transparency and independence respond to similar economic and institutional determinants: levels of both tend to have increased over time in more open economies, for example. But some of the determinants of the two dimensions of central banking arrangements also differ: where we find that transparency has tended to rise in countries with deeper financial markets, levels of central bank independence have not. While trends in transparency are positively affected by the strength of 
political institutions, the same is not obviously true of trends in independence.

Finally, we show that outcomes like the level and variability of inflation are significantly affected by both central bank independence and transparency. Disentangling the impact of the two dimensions of central bank arrangements is difficult not surprisingly, given that they respond to similar determinants. But none of this is to question that trends in central bank independence and transparency have been strongly upward or that these developments matter importantly for policy. 


\section{References}

Bade, Robert and Micheal Parkin (1982), Central Bank Laws and Monetary Policy, University of Western Ontario, Manuscript.

Bini-Smaghi, Lorenzo, and Daniel Gros (2001), "Is the ECB Sufficiently Accountable and Transparent?" European Network of Economic Policy Research Institutes Working Paper No. 7.

Blinder, Alan (1998), Central Banking in Theory and Practice, Cambridge, Mass.: MIT Press.

Clare, Andrew and Roger Courtenay (2001), "Assessing the Impact of Macroeconomic News Announcements on Securities Prices under Different Monetary Regimes," Bank of England Working Paper No. 125.

Crowe, Christopher and Ellen Meade (2008), "Central Bank Independence and Transparency: Evolution and Effectiveness," European Journal of Political Economy 24, pp. 763-777.

Cukierman, Alex (1992), Central Bank Strategy, Credibility and Independence: Theory and Evidence, Cambridge, Mass.: MIT Press.

Cukierman, Alex, Steve Webb, and B. Neyapti (1992), "Measuring the Independence of Central Banks and its Effect on Policy Outcomes," World Bank Economic Review 6, pp. 353-398.

Debelle, Guy and Stanley Fischer (1994), "How Independent Should a Central Bank Be?" in Jeffrey Fuhrer (ed), Goals, Guidelines and Constraints Facing Monetary Policymakers, Federal Reserve Bank of Boston, pp. 195-221.

De Haan, Jakob, Fabian Amtenbrink, and Sandra Waller (2004), "The Transparency and Credibility of the European Central Bank," Journal of Common Market Studies 42, pp. 775-794.

Dincer, Nergiz and Barry Eichengreen (2008), "Central Bank Transparency: Where, Why and With What Effects?" in Jean-Philippe Touffut (ed.), Central Banks as Economic Institutions, Cheltenham: Edward Elgar.

Dincer, Nergiz and Barry Eichengreen (2010), "Central Bank Transparency: Causes, Consequences and Updates," Theoretical Inquires in Law 11 (1). 
Eijffinger, Sylvester and Petra Geraats (2006), "How Transparent Are Central Banks?" European Journal of Political Economy 22, pp. 1-22.

Eijffinger, Sylvester and Eric Schaling (1993), "Central bank independence in twelve industrial countries," Banca Nazionale del Lavoro Quarterly Review 184, pp. 64-68.

Fry, M., D. Julius, L. Mahadeva, S. Roger, and G. Sterne (2000), "Key Issues in the Choic of Monetary Policy Framework," in L. Mahadeva and G. Sterne (eds), Monetary Policy Frameworks in a Global Context, London: Routledge, pp. 1-216.

Grilli, Vittorio, Donato Masciandaro, and Guido Tabellini (1991), "Political and Monetary Institutions and Public Financial Policies in the Industrial Countries," Economic Policy 6, pp. 341-392.

Haggard, Stephan and Robert Kaufman (1995), The Political Economy of Democratic Transitions, Princeton University Press.

Ilzetzki, Ethan, Carmen Reinhard and Kenneth Rogoff (2008), "Exchange Rate Arrangements Entering the 21st Century: Which Anchor Will Hold?," unpublished manuscript, University of Maryland and Harvard University.

Jacome, Luis I. and Francisco Vazquez (2008), "Any link between legal central bank independence and inflation? Evidence from Latin America and the Caribbean,” European Journal of Political Economy 24, pp. 788-801.

Siklos, Pierre L. (2002), The Changing Face of Central Banking: Evolutionary Trends Since World War II, Cambridge University Press.

Mishkin, Frederic (2004), "Can Central Bank Transparency Go Too Far?" NBER Working Paper No. 10829.

Rogoff, Kenneth (1985), "The Optimal Degree of Commitment to a Monetary Target," Quarterly Journal of Economics 100, pp. 1169-1190.

Siklos, Pierre L. (2011), “Central Bank Transparency: Another Look,” Applied Economics Letters 18, pp. 929-933.

Walsh, Carl (2003), Monetary Theory and Policy, Cambridge, Mass.: MIT Press. 


\section{APPENDIX A1. Construction of Central Bank Transparency Index}

We obtained information on central bank transparency from central banks' websites where possible. ${ }^{34)}$ These websites uniformly provide information for the most recent year; in some cases they also provide information for earlier years. We then filled in remaining gaps by referring to individual central bank annual reports and, where necessary, additional publications. The publications we used are housed in the IMF Law Library and the UC Berkeley Law Library.

The resulting index of central bank transparency is the sum of the scores for answers to the fifteen questions below $(\min =0, \max =15)$.

\section{Political Transparency}

Political transparency refers to openness about policy objectives. This comprises a formal statement of objectives, including an explicit prioritization in case of multiple goals, a quantification of the primary objective(s), and explicit institutional arrangements.

(a) Is there a formal statement of the objective(s) of monetary policy, with an explicit prioritization in case of multiple objectives?

- No formal objective $(\mathrm{s})=0$.

- Multiple objectives without prioritization $=1 / 2$.

- One primary objective, or multiple objectives with explicit priority $=1$.

(b) Is there a quantification of the primary objective(s)?

- $\mathrm{No}=0$.

- Yes $=1$.

(c) Are there explicit contacts or other similar institutional arrangements between the monetary authorities and the government?

- No central bank contracts or other institutional arrangements $=0$.

- Central bank without explicit instrument independence or contract =1/2.

34) Exactly the same procedures were followed in gathering data on central bank independence; see below. 
- Central bank with explicit instrument independence or central bank contract although possibly subject to an explicit override procedure $=1$.

\section{Economic Transparency}

Economic transparency focuses on the economic information that is used for monetary policy. This includes economic data, the model of the economy that the central bank employs to construct forecasts or evaluate the impact of its decisions, and the internal forecasts (model based or judgmental) that the central bank relies on.

(a) Is the basic economic data relevant for the conduct of monetary policy publicly available? (The focus is on the following five variables: money supply, inflation, GDP, unemployment rate and capacity utilization.)

- Quarterly time series for at most two out of the five variables $=0$.

- Quarterly time series for three or four out of the five variables =1/2.

- Quarterly time series for all five variables $=1$.

(b) Does the central bank disclose the macroeconomic model(s) it uses for policy analysis?

- $\mathrm{No}=0$.

- Yes $=1$.

(c) Does the central bank regularly publish its own macroeconomic forecasts?

- No numerical central bank forecasts for inflation and output $=0$.

- Numerical central bank forecasts for inflation and/or output published at less than quarterly frequency $=1 / 2$.

- Quarterly numerical central bank forecasts for inflation and output for the medium term (one to two years ahead), specifying the assumptions about the policy instrument (conditional or unconditional forecasts) $=1$.

\section{Procedural Transparency}

Procedural transparency is about the way monetary policy decisions are taken.

(a) Does the central bank provide an explicit policy rule or strategy that describes its monetary policy framework? 
- $\mathrm{No}=0$.

- Yes $=1$.

(b) Does the central bank give a comprehensive account of policy deliberations (or explanations in case of a single central banker) within a reasonable amount of time?

- No or only after a substantial lag (more than eight weeks) $=0$.

- Yes, comprehensive minutes (although not necessarily verbatim or attributed) or explanations (in case of a single central banker), including a discussion of backward and forward-looking arguments $=1$.

(c) Does the central bank disclose how each decision on the level of its main operating instrument or target was reached?

- No voting records, or only after substantial lag (more than eight weeks) $=0$.

- Non-attributed voting records $=1 / 2$.

- Individual voting records, or decision by single central banker $=1$.

\section{Policy Transparency}

Policy transparency means prompt disclosure of policy decisions, together with an explanation of the decision, and an explicit policy inclination or indication of likely future policy actions.

(a) Are decisions about adjustments to the main operating instrument or target announced promptly?

- No or only after the day of implementation $=0$.

- Yes, on the day of implementation $=1$.

(b) Does the central bank provide an explanation when it announces policy decisions?

- $\mathrm{No}=0$.

- Yes, when policy decisions change, or only superficially =1/2.

- Yes, always and including forwarding-looking assessments $=1$.

(c) Does the central bank disclose an explicit policy inclination after every policy meeting or an explicit indication of likely future policy actions (at least quarterly)? 
- $\mathrm{No}=0$.

- Yes $=1$.

\section{Operational Transparency}

Operational transparency concerns the implementation of the central bank's policy actions. It involves a discussion of control errors in achieving operating targets and (unanticipated) macroeconomic disturbances that affect the transmission of monetary policy. Furthermore, the evaluation of the macroeconomic outcomes of monetary policy in light of its objectives is included here as well.

(a) Does the central bank regularly evaluate to what extent its main policy operating targets (if any) have been achieved?

- No or not very often (at less than annual frequency) $=0$.

- Yes but without providing explanations for significant deviations = 1/2.

- Yes, accounting for significant deviations from target (if any); or, (nearly) perfect control over main operating instrument/target $=1$.

(b) Does the central bank regularly provide information on (unanticipated) macroeconomic disturbances that affect the policy transmission process?

- No or not very often $=0$.

- Yes but only through short-term forecasts or analysis of current macroeconomic developments (at least quarterly) $=1 / 2$.

- Yes including a discussion of past forecast errors (at least annually) $=1$.

(c) Does the central bank regularly provide an evaluation of the policy outcome in light of its macroeconomic objectives?

- No or not very often (at less than annual frequency) $=0$.

- Yes but superficially =1/2.

- Yes, with an explicit account of the contribution of monetary policy in meeting the objectives $=1$. 


\section{APPENDIX A2. Criteria List for LVAU and LVAW (Legal Central Bank Independence Indices of Cukierman, Webb and Neyapti 2002)}

\begin{tabular}{|c|c|c|c|}
\hline & & Weight & Codes \\
\hline \multirow[t]{25}{*}{1} & Chief Executive Officer (CEO) & 0.20 & \\
\hline & a. Term of Office & & \\
\hline & Over 8 years & & 1.00 \\
\hline & 6 to 8 years & & 0.75 \\
\hline & 5 years & & 0.50 \\
\hline & 4 years & & 0.25 \\
\hline & Under 4 years or at the discretion of appointer & & 0.00 \\
\hline & b. Who appoints CEO? & & \\
\hline & Board of central bank & & 1.00 \\
\hline & $\begin{array}{l}\text { A council of the central bank board, executive branch, and } \\
\text { legislative branch }\end{array}$ & & 0.75 \\
\hline & Legislature (congress, king) & & 0.50 \\
\hline & Executive collectively (e.g. council of ministers) & & 0.25 \\
\hline & $\begin{array}{l}\text { One or two members of the executive branch (prime minister, president, or } \\
\text { any other } \mathrm{m} \text {.) }\end{array}$ & & 0.00 \\
\hline & c. Dismissal & & \\
\hline & No provision for dismissal & & 1.00 \\
\hline & Only for reasons not related to policy (incapacity or violation of law) & & 0.83 \\
\hline & At the discretion of central bank board & & 0.67 \\
\hline & At legislature' $s$ discretion & & 0.50 \\
\hline & Unconditional dismissal possible by legislature & & 0.33 \\
\hline & At executive' s discretion & & 0.17 \\
\hline & Unconditional dismissal possible by executive or not mentioned & & 0.00 \\
\hline & d. May CEO hold other offices in government? & & \\
\hline & No & & 1.00 \\
\hline & Only with permission of the executive branch & & 0.50 \\
\hline & No rule against CEO holding another office & & 0.00 \\
\hline \multirow[t]{12}{*}{2} & Policy Formulation & 0.15 & \\
\hline & a. Who formulates monetary policy? & & \\
\hline & Bank alone & & 1.00 \\
\hline & Bank participates, but has little influence & & 0.67 \\
\hline & Bank only advises governmet & & 0.33 \\
\hline & Bank has no say & & 0.00 \\
\hline & b. Who has final word in resolution of conflict? & & \\
\hline & The bank, on issues clearly defined in the law as its objectives & & 1.00 \\
\hline & $\begin{array}{l}\text { Government, on policy issues not clearly defined as the bank's goals or in } \\
\text { case of conflict within bank }\end{array}$ & & 0.80 \\
\hline & $\begin{array}{l}\text { A council of the central bank, executive branch, and legislative branch gives } \\
\text { final decision }\end{array}$ & & 0.60 \\
\hline & The legislature has final authority on policy issues & & 0.40 \\
\hline & $\begin{array}{l}\text { The executive branch on policy issues, subject to due process and possible } \\
\text { protest by CB }\end{array}$ & & 0.20 \\
\hline
\end{tabular}




\begin{tabular}{|c|c|c|c|}
\hline & & Weight & Codes \\
\hline & The executive branch has unconditional priority & & 0.00 \\
\hline & c. Role in the government' $s$ budgetary process & & \\
\hline & Central bank active & & 1.00 \\
\hline & Central bank has no influence & & 0.00 \\
\hline \multirow[t]{7}{*}{3} & Objectives & 0.15 & \\
\hline & $\begin{array}{l}\text { Price stability mentioned as the major or only objective in the charter, and in } \\
\text { case of conflict with government CB has final authority to pursue policies } \\
\text { aimed at achieving this goal }\end{array}$ & & 1.00 \\
\hline & Price stability is the only objective & & 0.80 \\
\hline & $\begin{array}{l}\text { Price stability is only one goal, with other compatible objectives, such as a } \\
\text { stable banking system }\end{array}$ & & 0.60 \\
\hline & $\begin{array}{l}\text { Price stability is only one goal, with potentially conflicting objectives, such } \\
\text { as a full employment }\end{array}$ & & 0.40 \\
\hline & No objectives stated in the bank charter & & 0.20 \\
\hline & Stated objectives do not include price stability & & 0.00 \\
\hline \multirow[t]{30}{*}{4} & Limitations on lending to the government & & \\
\hline & a. Advances (limitation on nonsecuritized lending) & 0.15 & \\
\hline & No advances permitted & & 1.00 \\
\hline & $\begin{array}{l}\text { Advances permitted, but with strict limits (e.g. absolute cash amounts or up } \\
\text { to } 15 \text { percent of government revenue) }\end{array}$ & & 0.67 \\
\hline & $\begin{array}{l}\text { Advances permitted, and the limits are loose (e.g. over } 15 \text { percent of } \\
\text { government revenue) }\end{array}$ & & 0.33 \\
\hline & No legal limits on lending & & 0.00 \\
\hline & b. Securitized lending & 0.10 & \\
\hline & Not permitted & & 1.00 \\
\hline & Permitted, but with strict limits (e.g. up to 15 percent of government revenue) & & 0.67 \\
\hline & Permitted, and the limits are loose (e.g., over 15 percent of government revenue) & & 0.33 \\
\hline & No legal limits on lending & & 0.00 \\
\hline & c. Terms of lending (maturity, interest, amount) & 0.10 & \\
\hline & Controlled by the bank & & 1.00 \\
\hline & Specified by the bank charter & & 0.67 \\
\hline & Agreed between the central bank and the executive & & 0.33 \\
\hline & Decided by the executive branch alone & & 0.00 \\
\hline & d. Potential borrowers from the bank & 0.05 & \\
\hline & Only the central government & & 1.00 \\
\hline & All levels of government (state as well as central) & & 0.67 \\
\hline & Those mentioned above and public enterprises & & 0.33 \\
\hline & Public and private sector & & 0.00 \\
\hline & e. Limits on central bank lending defined in & 0.025 & \\
\hline & Currency amounts & & 1.00 \\
\hline & Shares of central bank demand liabilities or capital & & 0.67 \\
\hline & Shares of government revenue & & 0.33 \\
\hline & Shares of government expenditures & & 0.00 \\
\hline & f. Maturity of loans & 0.025 & \\
\hline & Within 6 months & & 1.00 \\
\hline & Within 1 year & & 0.67 \\
\hline & More than 1 year & & 0.33 \\
\hline
\end{tabular}




\begin{tabular}{|l|c|c}
\hline & Weight & Codes \\
\hline No mention of maturity in the law & 0.00 \\
\hline g. Interest rates on loans must be & 0.025 & \\
\hline Above minimum rates & & 0.75 \\
\hline At market rates & & 0.50 \\
\hline Below maximum rates & 0.25 \\
\hline Interest rate is not mentioned & 0.00 \\
\hline No interest on government borrowing from the central bank & \\
\hline $\begin{array}{l}\text { Central Bank prohibited from buying or selling government securities in the } \\
\text { primary market }\end{array}$ & 0.025 & \\
\hline Yes & & 1.00 \\
\hline No & & 0.00 \\
\hline
\end{tabular}

Note : The eight aggregate criteria are aggregated from the 16 initial measures as follows:

1. Four variables concerned with the independence of the CEO are aggregated with equal weights, i.e. $(1 a+1 b+1 c+1 d) / 4$;

2. The three policy formulation variables $2 \mathrm{a}, 2 \mathrm{~b}$ and $2 \mathrm{c}$ are aggregated (with weights $0.5,0.25,0.25$, respectively) into one variable;

3. Objectives criterion, 3.

4. Advances criterion under limits on lending;

5. Securitized lending under limits on lending;

6. Terms of Lending criterion under limits on lending;

7. Potential borrowers from the bank criterion under limits on lending

8. Four criteria, $4 \mathrm{e}, 4 \mathrm{f}, 4 \mathrm{~g}, 4 \mathrm{~h}$ on limits on lending are aggregated to one using equal weights, namely $(4 \mathrm{e}+4 \mathrm{f}+4 \mathrm{~g}+4 \mathrm{~h}) / 4$

From these 8 aggregated variables two indices are computed. LVAU is the unweighted average of the 8 aggregated variables whereas LVAW is the weighted average where the weights are given in Column 'weight.' 


\section{APPENDIX A3. Criteria List for Extended Legal Central Bank Independence Indices: CBIU and CBIW}

\begin{tabular}{|c|c|c|c|}
\hline & & Weight & Codes \\
\hline \multirow[t]{28}{*}{1} & Chief Executive Officer (CEO) & 0.10 & \\
\hline & a. Term of Office & & \\
\hline & More than the presidential/Prime Minister period & & 1.00 \\
\hline & The period does not coincide & & 0.67 \\
\hline & Same period as the executive branch & & 0.33 \\
\hline & Less than executive branch or not specified in the law & & 0.00 \\
\hline & b. Who appoints CEO? & & \\
\hline & Board of central bank & & 1.00 \\
\hline & A council of the central bank board, executive branch, and legislative branch & & 0.75 \\
\hline & Legislature & & 0.50 \\
\hline & Executive collectively (e.g. council f ministers) & & 0.25 \\
\hline & One or two members of the executive branch & & 0.00 \\
\hline & c. Dismissal & & \\
\hline & No provision for dismissal & & 1.00 \\
\hline & Only for reasons not related to policy & & 0.83 \\
\hline & At the discretion of central bank board & & 0.67 \\
\hline & At legislature' s discretion & & 0.50 \\
\hline & Unconditional dismissal possible by legislature & & 0.33 \\
\hline & At executive' $s$ discretion & & 0.17 \\
\hline & Unconditional dismissal possible by executive & & 0.00 \\
\hline & d. May CEO hold other offices in government? & & \\
\hline & No & & 1.00 \\
\hline & Only with permission of the executive branch & & 0.50 \\
\hline & No rule against CEO holding another office & & 0.00 \\
\hline & e. Is there any reappointment for CEO? & & \\
\hline & No & & 1.00 \\
\hline & Restricted to 2 consecutive terms & & 0.50 \\
\hline & Yes & & 0.00 \\
\hline \multirow[t]{11}{*}{2} & Policy Formulation & 0.15 & \\
\hline & a. Who formulates monetary policy? & & \\
\hline & Bank alone & & 1.00 \\
\hline & Bank participates, but has little influence & & 0.67 \\
\hline & Bank only advises government & & 0.33 \\
\hline & Bank has no say & & 0.00 \\
\hline & b. Who has final word in resolution of conflict? & & \\
\hline & The bank, on issues clearly defined in the law as its objectives & & 1.00 \\
\hline & $\begin{array}{l}\text { Government, on policy issues not clearly defined as the bank' s goals or in } \\
\text { case of conflict within bank }\end{array}$ & & 0.80 \\
\hline & A council of the central bank, executive branch, and legislative branch & & 0.60 \\
\hline & The legislature, on policy issues & & 0.40 \\
\hline
\end{tabular}




\begin{tabular}{|c|c|c|c|}
\hline & & Weight & Codes \\
\hline & $\begin{array}{l}\text { The executive branch on policy issues, subject to due process and possible } \\
\text { protest by the bank }\end{array}$ & & 0.20 \\
\hline & The executive branch has unconditional priority & & 0.00 \\
\hline & c. Role in the government' $s$ budgetary process & & \\
\hline & Central bank approves the budget & & 1.00 \\
\hline & Legally required to provide opinion on technical aspects & & 0.50 \\
\hline & Central bank has no influence & & 0.00 \\
\hline & d. Who formulates exchange rate policy? & & \\
\hline & Bank alone & & 1.00 \\
\hline & Bank participates, but has little influence & & 0.67 \\
\hline & Bank only advises governmet & & 0.33 \\
\hline & Bank has no say & & 0.00 \\
\hline \multirow[t]{7}{*}{3} & Objectives & 0.15 & \\
\hline & $\begin{array}{l}\text { Price stability is the major or only objective in the charter, and the central bank } \\
\text { has the final word in case of conflict with other government objectives }\end{array}$ & & 1.00 \\
\hline & Price stability is the only objective & & 0.80 \\
\hline & $\begin{array}{l}\text { Price stability is only one goal, with other compatible objectives, such as a } \\
\text { stable banking system }\end{array}$ & & 0.60 \\
\hline & $\begin{array}{l}\text { Price stability is only one goal, with potentially conflicting objectives, such as a } \\
\text { full employment }\end{array}$ & & 0.40 \\
\hline & No objectives stated in the bank charter & & 0.20 \\
\hline & Stated objectives do not include price stability & & 0.00 \\
\hline \multirow[t]{23}{*}{4} & Limitations on lending to the government & & \\
\hline & a. Advances (limitation on nonsecuritized lending) & 0.15 & \\
\hline & No advances permitted & & 1.00 \\
\hline & $\begin{array}{l}\text { Advances permitted, but with strict limits (e.g. up to } 15 \text { percent of government } \\
\text { revenue) }\end{array}$ & & 0.67 \\
\hline & $\begin{array}{l}\text { Advances permitted, and the limits are loose (e.g. over } 15 \text { percent of government } \\
\text { revenue) }\end{array}$ & & 0.33 \\
\hline & No legal limits on lending & & 0.00 \\
\hline & b. Securitized lending & 0.10 & \\
\hline & Not permitted & & 1.00 \\
\hline & Permitted, but with strict limits (e.g. up to 15 percent of government revenue) & & 0.67 \\
\hline & $\begin{array}{l}\text { Permitted, and the limits are loose (e.g., over } 15 \text { percent of government } \\
\text { revenue) }\end{array}$ & & 0.33 \\
\hline & No legal limits on lending & & 0.00 \\
\hline & c. Terms of lending (maturity, interest, amount) & 0.10 & \\
\hline & Controlled by the bank & & 1.00 \\
\hline & Specified by the bank charter & & 0.67 \\
\hline & Agreed between the central bank and the executive & & 0.33 \\
\hline & Decided by the executive branch alone & & 0.00 \\
\hline & d. Potential borrowers from the bank & 0.05 & \\
\hline & Only the central government & & 1.00 \\
\hline & All levels of government (state as well as central) & & 0.67 \\
\hline & Those mentioned above and public enterprises & & 0.33 \\
\hline & Public and private sector & & 0.00 \\
\hline & e. Limits on central bank lending defined in & 0.025 & \\
\hline & Currency amounts & & 1.00 \\
\hline
\end{tabular}




\begin{tabular}{|c|c|c|c|}
\hline & & Weight & Codes \\
\hline & Shares of central bank demand liabilities or capital & & 0.67 \\
\hline & Shares of government revenue & & 0.33 \\
\hline & Shares of government expenditures & & 0.00 \\
\hline & f. Maturity of loans & 0.025 & \\
\hline & Within 6 months & & 1.00 \\
\hline & Within 1 year & & 0.67 \\
\hline & More than 1 year & & 0.33 \\
\hline & No mention of maturity in the law & & 0.00 \\
\hline & g. Interest rates on loans must be & 0.025 & \\
\hline & Above minimum rates & & 1.00 \\
\hline & At market rates & & 0.75 \\
\hline & Below maximum rates & & 0.50 \\
\hline & Interest rate is not mentioned & & 0.25 \\
\hline & No interest on government borrowing from the central bank & & 0.00 \\
\hline & $\begin{array}{l}\text { h. Central Bank prohibited from buying or selling government securities in the } \\
\text { primary market }\end{array}$ & 0.025 & \\
\hline & Yes & & 1.00 \\
\hline & No & & 0.00 \\
\hline \multirow[t]{26}{*}{5} & Board Members & 0.10 & \\
\hline & a. Term of Office & & \\
\hline & More than presidential/Prime Minister period or for a non-defined period & & 1.00 \\
\hline & For the same period as the President of the Republic with overlap & & 0.75 \\
\hline & Double process for the same period & & 0.50 \\
\hline & $\begin{array}{l}\text { Executive and private sector appoint the majority of directors for same period } \\
\text { or less }\end{array}$ & & 0.25 \\
\hline & Executive branch appoints the majority for the same period or less & & 0.00 \\
\hline & b. Who appoints board members? & & \\
\hline & Board of central bank & & 1.00 \\
\hline & A council of the central bank board, executive branch, and legislative branch & & 0.75 \\
\hline & Legislature & & 0.50 \\
\hline & Executive collectively (e.g. council f ministers) & & 0.25 \\
\hline & One or two members of the executive branch & & 0.00 \\
\hline & c. Dismissal & & \\
\hline & $\begin{array}{l}\text { Double process approved by the Senate or by a qualified majority and for } \\
\text { violations codified in legislation }\end{array}$ & & 1.00 \\
\hline & By an independent Central Bank Board & & 0.83 \\
\hline & $\begin{array}{l}\text { Double process with simple majority, based on policy decisions or due to } \\
\text { subjective reasons }\end{array}$ & & 0.67 \\
\hline & By executive branch or subordinated Central Bank Board due to legal reasons & & 0.50 \\
\hline & $\begin{array}{l}\text { By executive branch or subordinated Central Bank Board due to policy or } \\
\text { subjective reasons, or no legal provision }\end{array}$ & & 0.33 \\
\hline & d. May board members hold other offices in government? & & \\
\hline & No & & 1.00 \\
\hline & Only with permission of the executive branch & & 0.50 \\
\hline & No rule against board members holding another office & & 0.00 \\
\hline & e. Is there any reappointment for board members? & & \\
\hline & No & & 1.00 \\
\hline & Yes & & 0.00 \\
\hline
\end{tabular}




\begin{tabular}{|l|l|l}
\hline f. Is there any government representatives on board? & Weight & Codes \\
\hline No & & \\
\hline Yes, but without voting rights & 1.00 \\
\hline Yes & 0.50 \\
\hline
\end{tabular}

Note : The 24 criteria are aggregated into 9 criteria first as follows.

1. Five variables concerned with the independence of the CEO are aggregated with equal weights, i.e. $(1 a+1 b+1 c+1 d+1 e) / 5$;

2. The four policy formulation variables are aggregated with equal weights, i.e.

$(2 a+2 b+2 c+2 d) / 4$

3. Objectives criterion, 3.

4. Advances criterion under limits on lending;

5. Securitized lending under limits on lending;

6. Terms of Lending criterion under limits on lending;

7. Potential borrowers from the bank criterion under limits on lending

8. Four criteria, $4 e, 4 f, 4 g, 4 h$ on limits on lending are aggregated to one by using equal weights, namely $(4 \mathrm{e}+4 \mathrm{f}+4 \mathrm{~g}+4 \mathrm{~h}) / 4$

9. Six variables concerned with board members are aggregated with equal weights, i.e. $(5 a+5 b+5 c+5 d+5 e+5 f) / 6$

From these 9 aggregated variables two indices are computed. CBIU is the unweighted average of the 9 aggregated variables whereas CBIW is the weighted average where the weights are given in Column 'weight'. 


\section{APPENDIX B}

Table B1-a: Simple Correlations among Central Bank Independence Definitions

\begin{tabular}{c|c|c|c|c|c} 
& LVAU & LVAW & CBIU & CBIW & TI \\
\hline LVAU & 1 & & & & \\
\hline LVAW & 0.987 & 1 & & & \\
\hline CBIU & 0.990 & 0.983 & 1 & & \\
\hline CBIW & 0.982 & 0.990 & 0.993 & 1 & \\
\hline TI & 0.078 & 0.140 & 0.117 & 0.152 & 1 \\
\hline
\end{tabular}

Table B1-b: Rank Correlations among Central Bank Independence Definitions

\begin{tabular}{c|c|c|c|c|c}
\hline & LVAU & LVAW & CBIU & CBIW & TI \\
\hline LVAU & 1 & & & & \\
\hline LVAW & 0.988 & 1 & & & \\
\hline CBIU & 0.989 & 0.981 & 1 & & \\
\hline CBIW & 0.982 & 0.987 & 0.992 & 1 & \\
\hline TI & 0.157 & 0.204 & 0.128 & 0.156 & 1 \\
\hline
\end{tabular}


Table B2: Determinants of Transparency, Period Averages, Including Exchange Rate Regime, Shorter Sample ${ }^{12) 33}$

\begin{tabular}{|c|c|c|c|c|c|c|c|}
\hline & । & $\|$ & III & IV & V & VI & VII \\
\hline Constant & $\begin{array}{l}-0.09 \\
(-0.19)\end{array}$ & $\begin{array}{l}-0.93^{*} \\
(-2.14)\end{array}$ & $\begin{array}{l}-0.41 \\
(-1.14)\end{array}$ & $\begin{array}{c}0.42 \\
(0.85)\end{array}$ & $\begin{array}{l}-0.87^{*} \\
(-2.09)\end{array}$ & $\begin{array}{l}-1.35^{*} \\
(-3.21)\end{array}$ & $\begin{array}{c}-0.77 \\
(-1.92)\end{array}$ \\
\hline Past Inflation & $\begin{array}{c}1.12 \\
(1.63)\end{array}$ & $\begin{array}{c}0.41 \\
(0.54)\end{array}$ & $\begin{array}{c}0.93 \\
(1.28)\end{array}$ & $\begin{array}{l}1.59^{*} \\
(2.57)\end{array}$ & $\begin{array}{l}-0.03 \\
(-0.04)\end{array}$ & $\begin{array}{c}0.43 \\
(0.56)\end{array}$ & $\begin{array}{c}-0.03 \\
(-0.04)\end{array}$ \\
\hline ER Regime & $\begin{array}{l}0.19^{*} \\
(3.98)\end{array}$ & $\begin{array}{l}0.21^{*} \\
(4.03)\end{array}$ & $\begin{array}{l}0.16^{*} \\
(3.69)\end{array}$ & $\begin{array}{l}0.15^{*} \\
(3.17)\end{array}$ & $\begin{array}{l}0.22^{*} \\
(4.04)\end{array}$ & $\begin{array}{l}0.22^{*} \\
(4.40)\end{array}$ & $\begin{array}{l}0.18^{*} \\
(3.42)\end{array}$ \\
\hline Openness & $\begin{array}{l}-0.00 \\
(-1.66)\end{array}$ & $\begin{array}{l}-0.00 \\
(-1.54)\end{array}$ & $\begin{array}{l}-0.00 \\
(-1.36)\end{array}$ & $\begin{array}{l}-0.00 \\
(-1.73)\end{array}$ & $\begin{array}{l}-0.00 \\
(-1.79)\end{array}$ & $\begin{array}{l}-0.00^{*} \\
(-2.73)\end{array}$ & $\begin{array}{l}-0.00 \\
(-1.69)\end{array}$ \\
\hline Financial Depth & $\begin{array}{l}0.00^{*} \\
(2.41)\end{array}$ & $\begin{array}{l}0.00^{*} \\
(3.06)\end{array}$ & $\begin{array}{l}0.00^{*} \\
(3.19)\end{array}$ & $\begin{array}{l}0.00^{*} \\
(2.24)\end{array}$ & $\begin{array}{c}0.00 \\
(1.92)\end{array}$ & $\begin{array}{l}0.00^{*} \\
(2.31)\end{array}$ & $\begin{array}{c}0.00 \\
(1.75)\end{array}$ \\
\hline GDP per Capita & $\begin{array}{c}0.02 \\
(0.38)\end{array}$ & $\begin{array}{l}0.11^{*} \\
(2.02)\end{array}$ & $\begin{array}{c}0.06 \\
(1.31)\end{array}$ & $\begin{array}{c}-0.03 \\
(-0.60)\end{array}$ & $\begin{array}{l}0.11^{*} \\
(2.04)\end{array}$ & $\begin{array}{l}0.17^{*} \\
(3.11)\end{array}$ & $\begin{array}{l}0.11^{*} \\
(2.11)\end{array}$ \\
\hline Rule of Law & $\begin{array}{l}0.26^{*} \\
(2.52)\end{array}$ & & & & & & \\
\hline Political Stability & & $\begin{array}{c}0.04 \\
(0.61)\end{array}$ & & & & & \\
\hline Voice and Accountability & & & $\begin{array}{l}0.26^{*} \\
(4.27)\end{array}$ & & & & \\
\hline Government Efficiency & & & & $\begin{array}{l}0.39^{*} \\
(3.22)\end{array}$ & & & \\
\hline Democracy & & & & & $\begin{array}{c}0.01 \\
(1.12)\end{array}$ & & \\
\hline Autocracy & & & & & & $\begin{array}{l}-0.02^{*} \\
(-2.68)\end{array}$ & \\
\hline Polity & & & & & & & $\begin{array}{l}0.02^{*} \\
(2.21)\end{array}$ \\
\hline R-Squared & 0.45 & 0.40 & 0.49 & 0.49 & 0.40 & 0.43 & 0.43 \\
\hline
\end{tabular}

Notes : 1) * denotes significance at $5 \%$.

2) t-statistics in parentheses.

3) The definition of independent variables are as follows: Past inflation is the logarithmic value of 1 lagged inflation; ER Regime variable is taken from Reinhart and Rogoff (2010) and is the average of the period 1998-2007; openness is the share of the sum of exports and imports to GDP; financial depth is the ratio of M2 to GDP; GDP per capita is the logarithm of constant GDP per capita; rule of law, political stability, voice and accountability and government efficiency are from Governance Indicators Database; and democracy, autocracy and Polity are taken from Polity Database. 


\section{$<$ Abstract in Korean $>$}

\section{N. Nergiz Dincer*, Barry Eichengreen**}

본고는 서베이 등을 통해 1998 2010년 중 120개국 중앙은행의 투명성 및 독립성 지수를 구축하고, 이에 기반하여 중앙은행 투명성 및 독립성의 변화 추이 및 결정요인, 중앙은행 투명성 및 독립성의 거시경제적 효과 등을 분석하였다.

먼저 구축된 지수를 이용하여 장기 추이를 살펴본 결과, 분석대상 기간 중 중앙은행의 투명성 및 독립성이 선진국, 신흥국 및 개도국 모두에서 꾸준히 제고되어 온 것으로 나타났으며 이러한 추세는 금융위기 이후에도 지속된 것으로 나타났다. 다음으로 중앙은행의 투명성 및 독립성의 결정요인을 분석한 결과, 경제 개방도, 정치적 안정 등이 공통적으로 유의한 영향을 미치는 것으로 나타났다. 마지막으로 중앙은행의 투명성 및 독립성의 거시경제적 효과를 살펴보기 위해 동 지수들이 인플레이션 변동성에 미치는 영향을 분석한 결과, 중앙은행의 독립성과 투명성이 제고될수록 인플레이션 변동성이 낮아지는 것으로 나타났다.

* Turkish State Planning Organization

** University of California, Berkeley 